\title{
RECYCLING PHILADELPHIA V. NEW JERSEY: THE DORMANT COMMERGE CLAUSE, POSTINDUSTRIAL "NATURAL" RESOURCES, AND THE SOLID WASTE GRISIS
}

\author{
DAVID POMPER $\dagger$
}

As the "garbage barges" of New York" and Philadelphia ${ }^{2}$ dramatically illustrate, many cities and states are discovering that their ability to recycle or dispose of solid waste ${ }^{3}$ lags behind their propensity to pro-

† B.A. 1984, Swarthmore College; J.D. Candidate 1989, University of Pennsylvania. I am indebted to Professor Frank Goodman, to Lecturer in Law Joseph Manko, and to Jon Anderson and Rena Steinzor, for their helpful criticism of earlier drafts of this Comment-and to Professors Gerald and Marlene Pomper for their helpful criticism of earlier drafts of both this Comment and myself. Responsibility for remaining flaws in either is, of course, mine alone.

1 See, e.g., Gutis, The End Begins for Trash No One Wanted, N.Y. Times, Sept. 2, 1987, at B1, col. 3 (describing the end of the 162-day, 6000-mile odyssey of barge Mobro as the New York City Sanitation Department begins processing its 3,100 tons of trash); Soil on Troubled Waters, N.Y. Times, Apr. 29, 1987, at A34, col. 1 (editorial) (wandering garbage barge from Islip, N.Y. symbolizes urgency of waste-disposal problems).

2 See, e.g., Jaffe, Tons of City Ash Remain in Limbo on the High Seas, Philadelphia Inquirer, Feb. 12, 1988, at B1, col. 1 (discussing two barges, long at sea, with cargos of ash from Philadelphia municipal incinerators and no apparent destination).

3 The term "solid waste" is defined in the Resource Conservation and Recovery Act of 1976 (RCRA), Pub. L. No. 94-580, 90 Stat. 2795 (codified in scattered sections of 42 U.S.C. $\$ \S 6901-6987$ (1982 \& Supp. IV 1986 \& West Supp. 1988)), as "any garbage, refuse, sludge from a waste treatment plant, water supply treatment plant, or air-pollution control facility and other discarded material . ..." 42 U.S.C. § 6903 (27) (1982).

The Environmental Protection Agency (EPA), in regulations issued under the RCRA, has adopted several variants of this definition, depending upon the subject matter of the regulation. See, e.g., 40 C.F.R. $\S 240.101$ (y) (1988) (guidelines for thermal processing of solid wastes); $i d$. $\S 241.101$ (v) (guidelines for land disposal of residential, commercial, and institutional solid waste); $i d$. $\S 246.101(\mathrm{bb})$ (guidelines for sourceseparation of solid wastes); id. $\$ 247.101$ (i) (guidelines for procurement of products that contain recycled material); id. $\S 257.2$ (criteria for classification of solid waste disposal facilities and practices); 53 Fed. Reg. 33,405-33,406 (1988) (to be codified at 40 C.F.R. § 258.2) (criteria for municipal solid waste landfills).

An EPA-sponsored study estimated that as of 1984, the 133 million ton "municipal solid waste stream" consisted primarily of paper products $(37.1 \%)$, yard wastes (17.9\%), glass $(9.7 \%)$, food wastes $(8.1 \%)$, metals $(9.6 \%)$, and plastics $(7.2 \%)$. See Franklin associates, Gharacterization of Municipal Solid Waste in the United States 1960-2000 ch. 1, at 6, 8 (1986) (tables). Mirroring society, significant trends in the composition of solid wastes include projected increases in small appliances and consumer electronics, paper, containers, and packaging-particularly plastics. See $i d$. ch. 1 at 12-17. Solid waste broadly defined also includes an estimated 45 to 70 million tons per year of water treatment and sewage sludges, over 15 million tons of 
duce it. ${ }^{4}$ According to the U.S. Environmental Protection Agency (EPA), more than half of the states already face a "garbage crisis." These states endeavor to export their waste to other states ${ }^{6}$ and foreign countries $^{7}$ where disposal costs are lower. They also seek to protect their own disposal capacity ${ }^{8}$ by limiting access to disposal facilities to their own residents and industries. ${ }^{9}$ Like radioactive waste before it, ${ }^{10}$

street refuse, 100 million tons of nonhazardous industrial process waste, 86.3 million tons of boiler and incinerator ash, and 20 million tons of car hulks; varying and largely unknown portions of these wastes are also deposited in landfills. See id. ch. 2 at 8 (table).

4 The average American discarded a net of 2.93 pounds of municipal solid waste each day in 1984; this figure is expected to decrease slightly to 2.59 pounds per day by century's end. See Franklin Associates, supra note 3, ch. 1, at 21 (table). The nation's discards totaled 126.5 million tons in 1984 and are projected to increase marginally to 126.8 million tons over the same period. See id. ch. 1 , at 6 (table). These figures do not include the 6.5 million tons removed from the solid waste stream by incineration (projected to rise to 32 million tons by the year 2000) but do include tonnages approximately half as large comprising the residues from incineration. See id. ch. 1, at 6 (table); $i d$. ch. 2, at 5, 8 (table). Nor do they include recycling of 15.1 million tons, 10.2 percent of 1984 gross discards. See id. ch. 3, at 17.

- See 53 Fed. Reg. 33,321 (1988); see also Shabecoff, With No Room at the Dump, U.S. Faces a Garbage Crisis, N.Y. Times, June 29, 1987, at B8, col. 1 (charting national solid waste disposal costs and flows, with international comparisons); Corrections, N.Y. Times, June 30,1987, at A3, col. 1 (correcting previous day's figures for Miami waste output).

B See Forester, Solid Waste: There's a Lot More Coming, E.P.A. J., May 1988, at 11, 11-12. See generally Kelly, Carrying the Load, EnvTL. F., March-Apr. 1988, at 17, 17-18 (surveying states' responses to the garbage crisis); State-By-State Analysis of Solid Waste Programs and Costs, Inside EPA's Envtl. Pol'y Alert, Apr. 20, 1988, at 1 (same); State Survey Part II, Inside EPA's Envtl. Pol'y Alert, May 4, 1988, at 1 (same). New Jersey, the nation's most densely populated state, already exports $54 \%$ of its solid waste to six surrounding states. See id.

7 See After 2 Years, Ship Dumps Toxic Ash, N.Y. Times, Nov. 28, 1988, at A22, col. 3 (noting the mysterious finale of the global odyssey of a barge laden with toxic ash which apparently dumped its contents in Singapore); Ash Ships Head for Africa, N.Y. Times, June 12, 1988, $\S 1$, at 24 , col. 1 (noting rising public anger in West Africa at industrial nations' attempts to dump waste there).

${ }^{8}$ This Comment uses the term "disposal capacity" to mean space in landfills or a combination of processing capacity in resource recovery (trash-to-steam) facilities and landfill space for the ash that these plants generate. Nationwide, $92 \%$ of solid waste is disposed of in landfills. See Forester, supra note 6, at 11.

- See sources cited supra note 6 .

10 Seeking to protect the nation's nuclear program and responding to citizens' antipathy to radioactive waste transportation and disposal, Congress followed a two-track approach to siting disposal facilities. Congress initiated a long national process to select a single storage location for high-level radioactive waste. The siting process, conducted by the Department of Energy, met with stiff opposition at every proposed location. See, e.g., Knudson, Bullfrog County, Nev., (Pop. O) Fights Growth, N.Y. Times, Aug. 30, $1987, \S 1$, at 1 , col. 2 (describing Nevada's attempt to discourage selection by establishing the proposed site as "Bullfrog County," with no population, no government, and astronomical property taxes). Despite continuing problems, the Department has provisionally settled on a site in Nevada adjoining a nuclear weapons testing ground. See Schneider, Suddenly, Nuclear Waste Looks Very Visible Again, N.Y. Times, Sept. 18, 1988, at E4, col. 1. But see Wald, Work is Faltering on U.S. Repository for Atomic 
solid waste is becoming hot-though this time only in a political, not a physical, sense.

The Supreme Court rejected an early attempt by a state to refuse all exogenous refuse in Philadelphia $v$. New Jersey. ${ }^{11}$ Applying a dormant commerce clause analysis, the Court ruled that New Jersey was violating the Constitution by requiring nonresidents to bear the full burden of preserving one of New Jersey's natural resources-open land suitable for landfilling. ${ }^{12}$ Under the Court's reasoning, New Jersey did not "own" that resource and, therefore, had no right to hoard it. Leaving a loophole, however, the Court did not question a state's power to "restrict to state residents access to state-owned resources . . . or . . . spend state funds solely on behalf of state residents and businesses."13

Not surprisingly, states are taking advantage of that opening. In four recent cases, Maryland, ${ }^{14}$ the District of Columbia, ${ }^{15}$ Oregon, ${ }^{16}$ and Rhode Island ${ }^{17}$ thwarted challenges to their decisions to exclude exogenous garbage from landfills that they or their subdivisions owned and operated. Since $81 \%$ of the nation's landfills are owned and operated by state or local government, ${ }^{18}$ the practical impact of these rulings on the interstate transportation of solid waste is to let the exception swallow the Philadelphia v. New Jersey rule.

Waste, N.Y. Times, Jan. 17, 1989, at A1, col. 6 (noting that work is behind schedule and over budget).

Under the Low-Level Radioactive Waste Policy Act of 1980, Pub. L. No. 96-573, 94 Stat. 3347, superseded by Low-Level Radioactive Waste Policy Amendments Act of 1985, Pub. L. No. $99-240,99$ Stat. 1842 (1986) (codified at 42 U.S.C. $\S \S 2021 \mathrm{~b}-\mathrm{j}$ (Supp. IV 1986)), Congress made states responsible for disposing of all low-level radioactive waste produced within their borders, see 42 U.S.C. $\$ 2021 \mathrm{c}$ (Supp. IV 1986), while encouraging states to form compacts to operate regional disposal facilities. See 42 U.S.C. § 2021d(a)(2) (Supp. IV 1986). Seven regional compacts comprising 44 states have so far received congressional consent. See Omnibus Low-Level Radioactive Waste Interstate Compact Consent Act, Pub. L. No. 99-240, tit. II, 99 Stat. 1859 (1986) (codified at 42 U.S.C. $\S 2021 d$ (Supp. IV 1986)). This approach has had mixed results. See, e.g., Wald, A Time of Decision Nears on Nuclear Waste, N.Y. Times, Feb. $24,1985, \S 1$, at 1 , col. 4 (radioactive waste disposal problem has intensified as a result of $1980 \mathrm{Act}$ ).

11437 U.S. 617 (1978).

12 See id. at 628-29.

13 See id. at 627 n.6 (citations omitted).

14 See County Comm'rs v. Stevens, 299 Md. 203, 221-22, 473 A.2d 12, 21-22 (1984).

${ }^{15}$ See Shayne Bros., Inc. v. District of Columbia, 592 F. Supp. 1128, 1134 (D.D.C. 1984).

${ }^{16}$ See Evergreen Waste Sys., Inc. v. Metropolitan Serv. Dist., 643 F. Supp. 127, 132 (D. Or. 1986).

17 See Lefrancois v. Rhode Island, 669 F. Supp. 1204, 1211-12 (D.R.I. 1987).

${ }_{18}$ See 53 Fed. Reg. 33,318 (1988) (noting that municipal solid waste landfills are owned predominantly by local governments $(80 \%)$ with an additional $1 \%$ owned by state governments). 
Lefrancois $v$. Rhode Island offers a particularly compelling example because it involved the only generic-waste landfill in Rhode Island and the largest landfill still operating in New England. ${ }^{19}$ Yet the federal district court upheld a Rhode Island statute that instituted a complete ban on the dumping of exogenous wastes at the landfill despite the landfill's regional importance. ${ }^{20}$ The Lefrancois holding will no doubt prove tempting to other states seeking to restrict waste importation. ${ }^{21}$

The Lefrancois court reached the correct result. But the rule conditioning the power to exclude wastes on public ownership and operation of disposal facilities is based on a questionably drawn constitutional doctrine, the market participant exception, which is applied to an overly narrow view of the disposal market. Part I of this Comment will redraw the market participant exception to the dormant commerce clause in light of its function in courts' initial balancing of federal and state interests. Part II will then apply that framework to argue that a broadened exception should allow states to hoard "natural" resources that they have either created or actively preserved. Part III will examine the impact of this approach on the constitutionality of several means by which states are likely to attempt to conserve disposal capacity.

\section{The Market Particrpant Exception to the Dormant Gommerce Clause}

The dormant commerce clause empowers courts to strike down state laws that restrict free interstate commerce. The market participant exception protects state laws that affect only parties who transact business with the enacting state or its subdivisions. Section A of this Part sets forth reasons for reading the dormant commerce clause into article I, section 8 of the Constitution, and develops a general theory of the judiciary's role in applying the clause. Section B discusses the development and purpose of the market participant exception, suggesting that discrimination based on state residence is sometimes a legitimate goal that the exception enables states then to pursue. Section $\mathrm{C}$ then argues

${ }^{19}$ See Lefrancois, 669 F. Supp. at 1206.

${ }^{20} \mathrm{See}$ id. at 1207-12 (upholding R.I. GeN. Laws § 23-19-13.1 (Supp. 1988)). The statute superseded a contractual agreement, pursuant to R.I. GEN. LAws $\S 23-19$ 13.1 (1985), under which the plaintiff was allowed to bring exogenous waste to Central Landfill so long as it exported an equal amount of waste from the state. See Lefrancois, 669 F. Supp. at 1206, 1218.

${ }_{21}$ See Kelly, supra note 6, at 18 (noting that Ohio's Attorney General backed legislation restricting waste importation, believing it to be constitutional because of recent court rulings). 
that under this rationale, the market participant exception should be limited to cases where a state (1) is entitled to pursue a discriminatory end, and (2) pursues the end through appropriate, minimally burdensome means.

\section{A. The Dormant Commerce Clause}

The Framers called the Constitutional Convention largely to enact the commerce clause. ${ }^{22}$ For the first century of constitutional interpretation, the "negative" or "dormant" aspect of the clause was the most vital. ${ }^{23}$ This aspect empowers courts to strike down state legislation conflicting with the nationalizing policies of the commerce clause, thereby restricting the states even while Congress sleeps on its power to preempt them. ${ }^{24}$ The clause's "positive" aspect grants power to Congress, the scope and use of which have mushroomed since the 1887 Interstate Commerce Act. ${ }^{25}$ Under current doctrine, Congress has essentially unlimited power to regulate economic activity. ${ }^{26}$ Significantly, Congress may both void state laws that the dormant commerce clause would authorize, and authorize state laws that the dormant commerce clause would void. ${ }^{27}$ Despite its constitutional origins, then, the dormant commerce clause functions as a doctrine of federal common law-decisions under it remain open to congressional review. ${ }^{28}$

Commentary debating when courts fully subject to congressional review should apply the dormant commerce clause can be grouped into

${ }^{22}$ See Stern, That Commerce Which Concerns More States Than One, 47 HaRv. L. Rev. 1335, 1337-38 (1934); see also Regan, The Supreme Court and State Protectionism: Making Sense of the Dormant Commerce Clause, 84 Mrch. L. REv. 1091, 1114 n.55 (1986) (asserting that the Framers' fear of protectionism and retaliation was real but probably was not based on actual experience under the Articles of Confederation). 1988).

${ }^{23}$ See L. Tribe, American Constitutional Law $\$ 5-4$, at 306-07 (2d ed.

24 Congress's power to preempt derives not from the commerce clause, but from the supremacy clause, U.S. Const. art. VI, cl. 2. See Department of Revenue v. Association of Wash. Stevedoring Cos., 435 U.S. 734, 749 (1978).

${ }_{25}$ Ch. 104, 24 Stat. 379 (1887).

${ }^{26}$ See, e.g., Wickard v. Filburn, 317 U.S. 111, 118-29 (1942) (upholding congressional regulation of wheat grown for consumption on the farm). See generally L. TRIBE, supra note $23, \S \S 5-4$ to 5-6 (analyzing the contemporary view of the commerce clause powers).

${ }^{27}$ See Panhandle E. Pipeline Co. v. Public Serv. Comm'n, 332 U.S. 507, 521 (1947); Prudential Ins. Co. v. Benjamin, 328 U.S. 408, 418-427 (1946); Southern Pac. Co. v. Arizona, 325 U.S. 761, 769 (1945).

${ }_{28}$ See Monaghan, The Supreme Court 1974 Term-Foreword: Constitutional Common Law, 89 HaRv. L. REv. 1, 15-17 (1975); see also Redish \& Nugent, The Dormant Commerce Clause and the Constitutional Balance of Federalism, 1987 DukE L.J. 569, 601-03 (explaining the common-law status of commerce clause jurisprudence). 
three approaches. ${ }^{29}$ The first approach argues that the possibility of congressional review frees the courts to make value-oriented decisions under the dormant commerce clause. The proponents of this approach go on to argue that courts should pursue economic efficiency by way of free trade. ${ }^{30}$ The second approach argues that the courts should forego substantive review and police only procedure, scrutinizing state laws that discriminate against interests unrepresented in state politics. ${ }^{31}$ Oth-

29 Some scholars have advanced a fourth approach-that courts should never apply the dormant commerce clause. See Redish \& Nugent, supra note 28 at 617 ; see also Anson \& Schenkkan, Federalism, the Dormant Commerce Clause, and State-Owned Resources, 59 TEX. L. REv. 71, 91-97 (1980) (advocating this approach in the natural resources context). Whatever the merits of such critiques of the dormant commerce clause, it is unrealistic to expect the Court to abandon a doctrine that has been an important and firmly-rooted part of its federalism jurisprudence since Cooley v. Board of Wardens, 53 U.S. (12 How.) 299, 317-19 (1851). See generally L. TRIBE, supra note $23, \S \S 6-2$ to $6-4$ (discussing the history of judicial review of state regulation of interstate commerce). The existence and shape of exceptions to the dormant commerce clause therefore remain live issues; debate on them should be framed by proposing, at least at the outset, a valid basis for the general doctrine. See generally R. DwORKIN, LAw's EMPIRE 45-86 (1986) (arguing that a proper "interpretive attitude" requires an attempt to interpret generously the purpose of a legal rule before making decisions concerning the proper limits of the rule).

Without attempting here to respond in depth to these global critiques, it should also be noted that the problem of congressional inertia in the face of political polarization may present an even greater threat than congressional acceptance of economic inefficiency. Even if the Constitution demands judicial tolerance of the latter problem, as Professors Redish and Nugent assert, see Redish \& Nugent, supra note 28, at 592-99, hostility to the polarizing force of deliberately and unjustifiably discriminatory state laws is implicit in the very concept of a national constitution. Many members of Congress, moreover, are probably aware of Congress's fallibility in guarding against that threat. Congress is therefore institutionally "happy" to let stand a doctrine that delegates police duties to a politically less accountable branch. Cf. Fitts, The Vices of Virtue: A Political Party Perspective on Civic Virtue Reforms of the Legislative Process, 136 U. PA. L. REV. 1567, 1635-38 (1988) (commending as pragmatic Congress's use of "veiling" delegation strategies for ensuring that hard choices get made).

${ }^{30}$ See, e.g., Easterbrook, Antitrust and the Economics of Federalism, 26 J.L. \& ECON. 23, 45-46 (1983) (arguing that courts should maximize the "market" influence of competition among jurisdictions in defining the boundary between federal and state rules by linking "monopoly overcharges" to the polity adopting the regulation); Levmore, Interstate Exploitation and Judicial Intervention, 69 VA. L. REv. 563, 56770 (1983) (advocating a blend of "process" and "values" justifications for judicial intervention on behalf of free trade). See generally R. POSNER, Economic ANALYSIS of LAW $\S \S 26.1$ to 26.7 (3d ed. 1986) (discussing the "economics of federalism").

31 See, e.g., J. Ghoper, Judicial Review and the National Political Process 205-06 (1980) (arguing that the fact that "[s]tate and local legislatures contain no ... representatives of the central government, or of those persons outside the jurisdiction upon whom the impact of local laws may fall" provides a rationale for the courts' superintendence); J. ELY, DEMOCRACY AND DISTRUST 83-84 (1980) (arguing that the privileges and immunities clause and "self-operating dimension" given to the commerce clause by the Supreme Court are protective devices helping to guarantee "virtual representation"); L. TRIBE, supra note $23, \S 6-5$ (discussing contemporary doctrine and the theme of political representation); Eule, Laying the Dormant Commerce Clause to Rest, 91 YALE L.J. 425, 437-447 (1982) (urging that current dormant commerce clause 
erwise, economic efficiency would be constitutionally privileged above other values that state legislatures may pursue, and values that Congress may deliberately have sought to protect through its past inaction. ${ }^{32}$

Both of these approaches present problems. Even if we were to accept economic efficiency as privileged, ${ }^{33}$ it is far from clear why judicial review is the appropriate mechanism for examining state laws burdening this efficiency. The fact that inefficient state laws remain open to congressional review suggests that Congress should bear responsibility for reviewing such laws. Indeed, state laws that burden the national economy may be the ones most likely to attract congressional review. ${ }^{\mathbf{3 4}}$ Furthermore, nonrepresentation of nonresidents is not a procedural flaw; rather, it is fundamental to our federal system in which states retain a measure of independence from the national government. ${ }^{35}$

doctrine be replaced by a process-reinforcing approach rooted instead in the privileges and immunities clause); Smith, State Discriminations Against Interstate Commerce, 74 CAlif. L. Rev. 1203, 1209-10 (1986) (describing the Supreme Court's use of political process rationales invalidating discriminatory state regulations); Tushnet, Rethinking the Dormant Commerce Clause, 1979 WIs. L. REv. 125, 130-41 (analyzing the different forms of discrimination that state regulation might effect and arguing that each raises different "process" implications for judicial review).

${ }^{32}$ See, e.g., Eule, supra note 31, at 441-43 (criticizing value-oriented approaches to the dormant commerce clause).

${ }^{33}$ See generally Comment, Hood v. Dumond: A Study of the Supreme Court and the Ideology of Capitalism, 134 U. PA. L. REv. 657, 682-88 (1985) (arguing that the majority opinion in that case effected a dramatic shift in commerce clause analysis toward protecting a national free market).

${ }^{34}$ The point is not that Congress typically produces economically efficient legislation. Indeed, it does not. See D. Mayhew, Congress: The Electoral Connection 125-33 (1974); Fitts, supra note 29, at 1579-84. See generally Stigler, The Theory of Economic Regulation, 2 BELI J. EcoN. \& MGMT. ScI. 3 (1971) (analyzing legislation as a market in which firms deliver votes and other resources to politicians in exchange for applications of state power, such as subsidies, entry barriers, and price fixes, that give them concentrated benefits while arousing only dispersed, hence ineffective, opposition). The point is that nationally inefficient legislation that can pass in individual states will often lose on the national level. The same nationally organized economic special interests that dominate Congress and make it inefficient, see Olson, The Political Economy of Comparative Growth Rates, in The Political ECONOMX of GRowTH 19-23 (D. Mueller ed. 1983), may pressure Congress into preempting burdensome and/or conflicting state laws. See Elliot, Ackerman, \& Millian, Toward a Theory of Statutory Evolution: The Federalization of Environmental Law, 1 J.L. ECON. \& ORG. 313, 327 (1985) (arguing that the sudden emergence of federal environmental law resulted from industry's desire to preempt stringent and inconsistent laws obtained by nascent environmental organizations at the state level).

To save its scarce time, Congress can delegate the policing of state laws to administrative agencies. A first step in what may be such an administrative preemption process has already been taken in the field of landfill policy. See infra note 218 and accompanying text.

${ }^{35}$ See Rapaczynski, From Sovereignty to Process: The Jurisprudence of Federalism After Garcia, 1985 SuP. CT. REv. 341, 380-90 (arguing that independent state governments supported by constituencies smaller and varying in composition from na- 
In failing to suggest a role for the courts in reinforcing the congressional process, both of the approaches discussed above assume that Congress is a perfect protector of national interests. Yet as the Supreme Court recently recognized in Garcia v. San Antonio Metropolitan Transit Authority, ${ }^{36}$ states retain great influence in Congress. Dormant commerce clause jurisprudence should take Garcia seriously and recognize that the states' influence is capable of thwarting Congress's role as protector of the national interest. ${ }^{37}$ While Congress remains likely to respond to economically inefficient state regulations, ${ }^{38}$ it is less likely to encourage broad participation or promptly to mend tears in the political fabric of the union. ${ }^{39}$ Whether or not the possibility of such failure may ever warrant judicial invalidation of congressional action under the positive commerce clause, it should at least inform judicial action under the dormant commerce clause. Moreover, courts reviewing state laws are at least as competent to evaluate a law's threat to political unity as its economic impact.

This Comment, therefore, joins a third approach taken by prior commentary: ${ }^{40}$ the courts should wield the dormant commerce clause

tional interest groups provide both an important bulwark against tyranny and support for citizen participation).

s8 469 U.S. 528, 547-55 (1985).

${ }^{37}$ See, e.g., J. CHOPER, supra note 31, at 185-90 (focusing on the happy conclusion that "the federal political branches are fully capable of guarding against the states" being swallowed by a central monolith," but conceding in passing that "Madison's pessimistic forecast-that "measures will too often be decided according to their probable effect, not on the national prosperity and happiness, but on the prejudices, interests, and pursuits of the governments and people of the individual states'-has been markedly realized" (quoting The FEDERALIST No. 46, at 295 (J. Madison) (H. Lodge ed. 1888))); D. MAYHEW, supra note 34, at 53-59 (arguing that members of Congress gain more by providing particularized benefits limited to their own district than by joining with others to provide broader benefits).

s8 See Redish \& Nugent, supra note 28, at 605.

39 See Rapaczynski, supra note 35 , at 388.

[Since] federal legislators are primarily tied to the constituencies that elect them (that is, in practice, to the already-often nationally-organized interest groups in their districts), then they do not have any special incentive to strengthen the state governmental machinery which may be the most important factor in readjusting the local configuration of forces that in turn influences the actions of the national representatives.

Id.; see also A. DE Tocqueville, Democracy in AmeriCA 88 (P. Bradley ed. 1945).

The [legislatively centralized] social power . . . is constantly changing hands, because it is subordinate to the power of the people. It often forgets the maxims of wisdom and foresight in the consciousness of its strength. Hence arises its danger. Its vigor, and not its impotence, will probably be the cause of its ultimate destruction.

Id.

10 See Regan, supra note 22, at 1113-15 (asserting that protectionism is objectionable because it is fundamentally incompatible with the concept of political union and it 
primarily to void state laws that so threaten the health of the national political process that they ought not stand unless Congress expressly authorizes them. ${ }^{41}$ In other words, courts should consider whether a Congress focused on preserving and enriching the political culture of the Union would have authorized states to pass the challenged law. If the net effect of applying a state law is to strengthen the national political process, then the law should survive dormant commerce clause review. This third approach synthesizes the efficiency-oriented and process-reinforcing approaches. It takes from the former the idea that because dormant commerce clause courts are really acting as commonlaw courts, they are free to pursue "legislative" ends; it takes from the latter the idea that they should pursue ends likely to be underemphasized by the actual legislature. This view aims to "reinforce" the political process in the way that steel reinforces concrete-making its intact structure stronger, rather than plugging its leaks by correcting individual bad decisions.

\section{B. The Market Participant Exception}

This Section argues that the market participant exception makes sense as a corollary of the general principle that the dormant commerce clause should be applied to preserve the health of the national political process. It must first be admitted, however, that the historical stated purpose of the exception has been a different one: preserving the questionable value of "state sovereignty."

is likely to set off escalating cycles of resentment and retaliation); Varat, State "Citizenship" and Interstate Equality, 48 U. GHI. L. Rev. 487, 493 (1981) (advancing on more formalistic grounds a jurisprudence of state "citizenship" that would have substantially the same application); see also Rapaczynski, supra note 35, at 405-08 (advancing, as a limit to Congress's power under the positive commerce clause, a jurisprudence similarly aimed at preserving and enhancing the national political process).

41 The three approaches to the dormant commerce clause discussed in the text posit three alternative roles for the courts: free-trade enforcing, power balancing, and structure-preserving. These alternatives correspond, but not in chronological order, to the three phases of Professor Hurst's American history: the release of energy through the establishment of a national free-trade zone (1800-1870), the balancing of power $(1870-1900)$, and the constitution and preservation of the Union (1776-1800). See J. Hurst, Law and the Conditions of Freedom in the Nineteenth-Century UNITED States 39-42 (1956). Hurst argues that "the Gourt, rather than Congress, led in protecting multi-state areas of economic maneuver" through the dormant commerce clause and other aspects of commercial law. Id. at 50. This Comment argues that since Congress has more or less grasped that baton, the Court should move full circle to focus on preserving political unity. 


\section{The Development of the Exception}

The market participant exception has a brief history. Consistent with the national-free-market origins of the dormant commerce clause, the exception was born in a case affirming privatization. In American Yearbook Co. $v$. Askew, ${ }^{42}$ the Supreme Court summarily affirmed a federal district court decision upholding, against commerce clause attack, a Florida statute requiring that the state's public documents be printed within the state. The district court first noted that a state purchasing labor or materials acts as trustee for its residents. ${ }^{43} \mathrm{Im}$ pliedly, therefore, the state should be free to favor its own citizens even when a private purchaser would not. The court's major concern, however, was the potential interference with state proprietary activity if its every job specification were subject to commerce clause attack. ${ }^{44}$ While the district court's rationale was largely unsupported by precedent, ${ }^{45}$ the Supreme Court summarily affirmed the decision without discussing the market participant exception.

The Supreme Court first explicitly adopted the market participant exception in Hughes $v$. Alexandria Scrap Corp. ${ }^{48}$ In that case the Court upheld a statute whereby Maryland, in order to help rid the state of abandoned automobiles, paid a bounty to licensed scrap processors that crushed hulks. ${ }^{47}$ Virginia scrap processors challenged the statute because it rendered them ineligible for bounties unless they met documentation requirements more stringent than those imposed on Maryland processors. ${ }^{48}$ Writing for a six-member majority, Justice Powell reasoned that "Maryland has not sought to prohibit the flow of hulks, or to regulate the conditions under which it may occur. Instead, it has entered into the market itself to bid up their price." 49 Therefore, "Maryland's action . . . was [not] the kind of action with which the Com-

42409 U.S. 904 (1972), affg, 339 F. Supp. 719 (M.D. Fla. 1972).

43 See American Yearbook, 339 F. Supp. at 721.

14 See id. at $725 \&$ n.36.

45 See id. at 724 nn.27 \& 29. For a discussion and criticism of early state court precedents, see Blumoff, The State Proprietary Exception to the Dormant Commerce Clause: A Persistent Nineteenth-Century Anomaly, 1984 S. ILL. U.L.J. 73, 85-101.

46 U.S. 794 (1976).

47 See id. at 809-10 (upholding MD. ANN. Cone art. 661/2, §§ 5-201, 5-205 (1970 \& Supp. 1975), repealed by Acts of 1977 , ch. 14, § 1). The statute defined "hulks" as inoperative automobiles over eight years old. See id. at 798 .

48 The extra burden on out-of-state processors was contained in an amendment to the statute, and the amendment brought the suit. But the Court held that the statute was to be considered as though the loophole had been sealed from the start. See id. at 809.

49 Id. at 806. 
merce Clause is concerned."

In its next two opinions under the market participant exception, the Court expanded the doctrine. While in both Alexandria Scrap and American Yearbook the states were purchasers of services, the Court expanded the exception to uphold South Dakota's decision to sell cement manufactured at a state-owned factory only to state residents. ${ }^{51}$ In a later case, the Court applied the exception even though the state was the purchaser only in the loose sense of hiring subcontractors through a private general contractor. ${ }^{52}$

After this period of initial fecundity, the Court for the first time rejected a state defense under the market participant exception in South-Central Timber Development, Inc. v. Wunnicke. ${ }^{53}$ The vitality of the market participant exception has seemed especially questionable since Garcia $^{54}$ overruled National League of Cities v. Usery. ${ }^{55}$ Alexandria Scrap and National League of Cities were closely related; the two decisions were announced on the same day and drew support from the same five Justices. National League of Cities applied the tenth amendment as a limit to congressional power; it was not a dormant commerce clause case. However, the Alexandria Scrap exception was based partly on similar controversial notions of inherent state authority to avoid federal preemption. ${ }^{66}$ While National League of Cities lowered the ceiling on federal power over the states, and Alexandria Scrap poked a hole in the floor of state obligations to the Union, the effect of both cases was to enhance the states' power at the expense of national uniformity.

so Id. at 805 .

s1 See Reeves, Inc. v. Stake, 447 U.S. 429 (1980).

52 In White v. Massachusetts Council of Constr. Employers, Inc., 460 U.S. 204, 211 n.7, 214-15 (1983), the Court applied the exception to general contractors purchasing subcontractors' services on behalf of the city of Boston. See infra notes 86-87 and accompanying text.

s3 46.7 U.S. 82, 95-99 (1984); see G. GunTHer, Constitutional Law 306 (11th ed. 1985) (noting that Wunnicke was "the first Court ruling to reject a state defense under the market participant exception") (emphasis removed); see also infra notes 88-92 and accompanying text (discussing Wunnicke).

54 Garcia v. San Antonio Metro. Transit Auth., 469 U.S. 528, 557 (1985).

sB 426 U.S. 833 (1976).

s6 See id. at $842-52$ and Alexandria Scrap, 426 U.S. at 809 , for the pertinent sections of each decision which contributed to the controversy. This Comment assumes, however, that Garcia will remain good law despite the controversy and the possibility of National League of Cities rising from its grave. See Garcia, 469 U.S. 528, 580 (Rehnquist, J., dissenting) (claiming that the National League of Cities principle "will, I am confident, in time again command the support of a majority of this Court"). The assumption of unlimited congressional power presents a useful polar case, greatly simplifying the discussion. Any limits on congressional power to position the national economy in our increasingly interdependent world are likely to be slight. 
Despite its origination in a case related to National League of Cities, the market participant exception has apparently survived. Writing for a unanimous Court, Justice Blackmun recently reiterated the validity of the doctrine in Wisconsin Department of Industry, Labor, and Human Relations v. Gould. ${ }^{57}$ However, the Court refused to apply the doctrine to that case, holding that congressional action had preempted the state law at issue. ${ }^{88}$ And in New Energy Co. v. Limbach, ${ }^{89}$ the Court again unanimously endorsed the doctrine while declining to apply it. Significantly, Justice Scalia wrote the opinion. While Justice Powell, the author of Alexandria Scrap, has retired, six of the eight current Justices who have faced the issue while on the Court have joined at least one majority opinion applying the exception to uphold a discriminatory state law. ${ }^{60}$ Since Gould and New Energy mark the second and third consecutive cases ${ }^{61}$ in which the Court has declined to apply the exception, however, an examination of its underpinnings is warranted.

\section{The Basis for the Exception}

An examination of the rationale behind the market participant exception can be simplified by using, as a conceptual device, a hypothetical congress focused on making the federal system work. As discussed above, courts interpreting the dormant commerce clause should emulate such a congress rather than focus on economic efficiency ${ }^{62}$ Such a congress would localize decisionmaking in order to foster broad participation, even at the risk of allowing economically inefficient outcomes. It would strive to preserve states' abilities to respond to particularly local concerns and values. It would give states great leeway when experimen-

s7 475 U.S. 282,289 (1986).

s8 The issue was whether a Wisconsin law, under which the state in its procurement boycotted repeat violators of the National Labor Relations Act (NLRA), was preempted by the NLRA. The Court decided that the state law was preempted and that the market participant doctrine was no shield against preemption. See id. at 28691.

se 108 S. Ct. 1803, 1809 (1988).

60 Justices Brennan, Marshall, O’Gonnor, and Stevens joined now-Chief Justice Rehnquist's opinion in White v. Massachusetts Council of Constr. Employers, Inc., 460 U.S. 204, 205 (1983). Justice Blackmun wrote the majority opinion in Reeves, Inc. v. Stake, 447 U.S. 429,430 (1980). Justice Scalia recognized the validity of the doctrine in dictum in New Energy, 108 S. Ct. at 1809 . Justice Kennedy has not yet had occasion to rule on the issue, nor did he as a circuit judge. Only Justice White has continuously dissented from applications of the doctrine. See Regan, supra note 22, at 1284 \& n.534.

61 The first case in which the Court refused to apply the doctrine was SouthCentral Timber Dev., Inc., 467 U.S. at 95-99. See infra notes 88-92 and accompanying text.

${ }_{62}$ See supra notes $22-41$ and accompanying text. 
tation was needed to inform national action. ${ }^{63}$ And it would prohibit most purposefully discriminatory state laws. ${ }^{64}$ For both philosophical and practical reasons, however, it would authorize state laws that discriminate in order to reserve to state residents public goods paid for or created by state residents. Philosophically,

in the absence of special circumstances, only the members of a group providing a service have a legitimate claim of entitlement to it. Like other groups free to combine their members' efforts to produce collective benefits to be shared among the group, political communities, including states, have a prima facie justification for limiting distribution of their public goods to those who combined to provide them. ${ }^{65}$

Practically, just as property must be privatized in order to preserve the incentive to husband it, ${ }^{B 6}$ a doctrine allowing states to withhold resources they have created or collected is necessary to preserve the incentive for states to act. Such a doctrine may appear to sanction mere selfishness if viewed from an ex post perspective, ignoring the ex ante incentive effects. ${ }^{67}$ Yet without it, the public goods created by state activities, far from being enjoyed nationally, would simply disappear. ${ }^{68}$ Along with it would disappear the incentive to participate (or more precisely, the opportunity to build organizations that reward participation) in state politics. And along with that would disappear a major reinforcement rod in the national political process. ${ }^{69}$ Moreover, once the "Lockean" labor-value basis for this exception is widely understood, these types of state acts are unlikely to provoke hostility or cycles

${ }^{63}$ See New State Ice Co. v. Liebmann, 285 U.S. 262, 311 (1932) (Brandeis, J., dissenting) ("It is one of the happy incidents of the federal system that a single courageous State may, if its citizens choose, serve as a laboratory; and try novel social and economic experiments without risk to the rest of the country.").

64 See Regan, supra note 22, at 1110-37 (presenting the case for striking down state acts having a protectionist purpose).

Bs Varat, supra note 40, at 523; see also Wells \& Hellerstein, The GovernmentalProprietary Distinction in Constitutional Law, 66 VA. L. REv. 1073, 1130-31 (1980) (suggesting that a justification for maintaining the government-proprietary distinction embodied in the market participation exception to the dormant commerce clause is "state fiscal autonomy in spending its money or otherwise distributing its resources").

${ }^{66}$ See Hardin, The Tragedy of the Commons, 162 Scr. 1243, 1244-45 (1968).

${ }^{67}$ Cf. B. ACKerman, Reconstructing American Law 46-55 (1984) (contrasting the ex ante and ex post legal perspectives).

${ }^{88}$ See Varat, supra note 40, at 522-23 \& n.150.

68 See Rapaczynski, supra note 35, at 395-405.

7o See Varat, supra note 40 , at 523 (citing Michelman, Property, Utility, and Fairness: Comments on the Ethical Foundations of "Just Compensation" Law, 80 HaRv. L. Rev. 1165, 1204-05 (1967)). 
of retaliation. ${ }^{71}$

Thus, there are good reasons for the market participant exception that do not rely on concepts of "traditional state function." Accordingly, the exception should survive Garcia. Moreover, Garcia's holding (that because states' role in national political processes suffices to protect their authority, courts should not overrule Congress in the name of state sovereignty) is fully reconcilable with a doctrine that limits court intervention when Congress has not acted. In fact, the federal government's broad power to preempt state decisions ${ }^{\mathbf{7 2}}$ argues for granting states more, not less, leeway to legislate in the first instance.

\section{The Contours of the Exception: Balancing Ends and Means}

\section{The Permissibility of a Discriminatory End}

The preceding discussion suggests that "market participation" is a label for a type of proresident discrimination that serves a permissible end. Thus, one test that should precede application of the market participant exception is whether the end sought by the state is permissible-whether the resource that the state seeks to keep is one that the state in fact has a right to keep. The question is not whether the state has a "regulatory" purpose; the line between "participant" and "regulator" is notoriously difficult to draw. ${ }^{73}$ Many if not all state acts are both participatory and regulatory. For example, a state may enter business in competition with private firms in order to regulate their behavior. ${ }^{74}$ The regulatory purpose of such acts should not disqualify them from application of the "market participant" exception.

Whether the state has a right to keep a particular resource is ulti-

${ }^{71}$ Cf. Regan, supra note 22, at 1194 (arguing that one reason that discriminatory state spending should be permitted under the dormant commerce clause, whereas discriminatory state regulation and taxation should not, is that the former is less coercive than the latter, and therefore "less likely to produce resentment and retaliation").

${ }^{72}$ As the Court held in Gould, market participant activity is subject to congressional preemption. See Gould, 475 U.S. at 286-91.

${ }_{73}$ See generally Stone, Corporate Vices and Corporate Virtues: Do Public/Private Distinctions Matter?, 130 U. PA. L. REv. 1441, 1445-48 (1982) (arguing that "whatever lines [between public and private activities] may once have existed are closer than ever to obliteration").

74 See, e.g., Adams, A Novel Scheme for Securing Railroad Competition, THE NAtion, Jan. 12, 1871, at 21-22 (proposing that Massachusetts purchase a fifty mile length of railroad in an effort to regulate competition); see also T. MCCRAw, Prophets of Regulation 37 (1984) (praising Adams' plan as a seminal model for effective regulation). The Tennessee Valley Authority is perhaps the best-known example of the Federal Government's use of this strategy. See also Nebbia v. New York, 291 U.S. 502, 529-30 (1934) (noting that states or municipalities may enter business in competition with private proprietors, and thus effectively, although indirectly, control the prices the latter charge). 
mately a question of fairness, not simply a question of physical causation or of nominal ownership. ${ }^{75}$ Whether the state deserves credit for having actively created or sustained the good that it seeks to keep cannot be answered simply by reference to state property law, because the state defines property rights. ${ }^{76}$ Therefore, courts must turn to a more philosophical analysis to test whether a state is unjustifiably defining property into its own hands. ${ }^{77}$

When resources are wholly created by the state, almost any means to keep them should be acceptable; the resource may be purposefully and entirely denied to other states, at least absent congressional action. When the resource's value was created entirely by nature or by the nation as a whole, states may not try to hoard them; ${ }^{78}$ even the possessor state's power to pursue other legitimate goals, using means that create some hoarding effect, is severely limited. ${ }^{79}$ But landfills are a mixture. ${ }^{80}$ When the value is mixed, courts must examine the means the state chooses to use. The question is: does the threat to national political unity ${ }^{81}$ outweigh the participation-enhancing value of allowing the state to pass the particular legislation (which depends on the degree to which the state is entitled to the resource)? This is a balancing test,

${ }^{75}$ Cf. Casenote, Constitutional Law, 27 WAyNe L. Rev. 1575, 1589-95 (1981) (attacking Reeves v. Stake, 447 U.S. 429 (1980) for invoking an untenable, formalistic distinction between participation and regulation, but ultimately conceding that since a contrary result would have "den[ied] South Dakota the fruits of its labor. . . . the equities of the case seem to lie on the side of South Dakota, a fact which clearly played a part in the decision").

${ }^{76}$ See Board of Regents v. Roth, 408 U.S. 564, 577 (1972) ("Property interests . . . are not created by the Constitution. Rather, they are created and their dimensions are defined by existing rules or understandings that stem from an independent source such as state law ....".).

${ }_{77}$ See Toomer v. Witsell, 334 U.S. 385, 402 (1948) (proposing that the theory that states own raw natural resources within their borders is merely a legal fiction expressing states' power to preserve and regulate the exploitation of an important resource).

${ }^{78}$ See Regan, supra note 22, at 1110-43.

79 See, e.g., Philadelphia v. New Jersey, 437 U.S. 617, 627-29 (1978) (holding that New Jersey could not hoard open lands even if its ultimate purpose in doing so was to protect its citizens' health). The admittedly loose suggested inquiry into the political process effect of protective state legislation is thus cabined by the threshold question of whether the state is entitled to seek to protect a given resource.

${ }^{80}$ See infra notes $125-33$ and accompanying text.

81 The "threat to national unity" may generally be a function of the "burden on interstate commerce," as that phrase has been fleshed out in Pike v. Bruce Church, Inc., 397 U.S. 137 (1970), and its progeny. See Brown-Forman Distillers Corp. v. New York State Liquor Auth., 476 U.S. 573, 579 (1986); Bacchus Imports, Ltd. v. Dias, 468 U.S. 263, 270 (1984); Edgar v. MITE Corp., 457 U.S. 624, 643-46 (1982); Minnesota v. Clover Leaf Creamery Co., 449 U.S. 456, 472 (1981); Hughes v. Oklahoma, 441 U.S. 322, 336 (1979); Raymond Motor Transp., Inc. v. Rice, 434 U.S. 429, 44142 (1978); Hughes, 426 U.S. at 804; Great Atl. \& Pac. Tea Co. v. Cottrell, 424 U.S. 366,376 (1976). 
but not the standard Pike test for burdensome but "evenhanded" regulations that do not discriminate between states. ${ }^{82}$ Here, the state seeks to discriminate, and the issue is what means the state may use to achieve it.

\section{Finding the Appropriate Means}

Even when the state's end is justifiable, not all means of discriminating are necessarily acceptable. Although courts and commentators sometimes write as though the market participant exception would apply no matter what means the state used to pursue a "participatory" goal-implying that the doctrine simply creates an exception for certain ends with no means test ${ }^{83}$ - courts have generally, and appropriately, limited the exception to certain modes of state action.

The question of what modes are acceptable reached the Supreme Court in White v. Massachusetts Council of Construction Employers, Inc. ${ }^{84}$ and in South-Central Timber Development, Inc., v. Wunnicke. ${ }^{85}$ The apparent answer, for now, is that the line lies somewhere between the facts of those two cases. In White, a 7-2 Court upheld a Boston mayor's order that Boston residents be given half of all the jobs on cityfunded construction projects. ${ }^{86}$ The order included subcontractors that were not in formal privity with the city. Nonetheless, the Court found that such employees were "in a substantial if informal sense, "working for the city." "\$87 Therefore, the city was acting as a market participant in hiring them and might, if it chose, condition hiring on residency.

82 The Pike test is as follows:

Where the statute regulates evenhandedly to effectuate a legitimate local public interest, and its effects on interstate commerce are only incidental, it will be upheld unless the burden imposed on such commerce is clearly excessive in relation to the putative local benefits. ... [T] he extent of the burden that will be tolerated will of course depend on the nature of the local interest involved, and on whether it could be promoted as well with a lesser impact on interstate activities.

Pike, 397 U.S. at 142.

${ }_{83}$ See, e.g., South-Central Timber Deu., Inc., 467 U.S. at 103 (Rehnquist, J., dissenting) (claiming that it is unduly formalistic to strike an Alaska statute aimed at ensuring that private lumberers would hire Alaskans to process state-owned timber solely because the means chosen by the state were unacceptable); Note, South-Central Timber Development, Inc. v. Wunnicke: The Dormant Commerce Clause Fells Alaska's Primary Manufacture Requirement for the Sale of State-Owned Timber, 5 N. ILL. U.L. REV. 155, 178 (1984) ("[T]he entire market-participant doctrine is suspect in that it simply allows a state to defeat the goals of the commerce clause by adopting a different governmental posture.").

${ }^{84} 460$ U.S. 204 (1983).

85467 U.S. 82 (1984).

${ }^{86}$ See White, 460 U.S. at 204.

${ }^{87}$ See id. at 211 n.7. 
In Wunnicke, by contrast, the Court struck down a regulation under which Alaska sold timber from state lands only to bidders who would perform their initial lumber-processing within the state. ${ }^{88}$ The regulation's apparent purpose was to use Alaska's ownership of the timberlands as leverage to ensure that Alaskans would be hired to process the lumber. ${ }^{89}$ Alaska's goal was the same as Boston's goal in White attaching conditions to the transfer of state-owned resources in order to create jobs. Yet four of the six Justices reaching the issue held that Alaska was impermissibly seeking to impose "downstream regulation of the timber-processing market in which it is not a participant."

There may be good reasons to draw the line between Boston's restriction of transactions, in which it directly supplied the entire purchase price, and Alaska's restriction of a market in timber-processing, for which it indirectly supplied a proportionately minor input. ${ }^{91}$ But what these cases make clear is that the "participatory" character of state action is not always obvious. The term is a label representing a conclusion that the mode of state action at issue causes no more damage to the policies of the commerce clause than the state is entitled to inflict. $^{\mathbf{9 2}}$

Several reasons have been advanced to explain why a state puts

${ }^{88}$ See South-Central Timber Dev., Inc., 467 U.S. at 84 (striking down ALASKA ADMIN. CoDE, tit. 11, $\S 76.130$ (1974) (repealed July 1982)). The regulation did not in terms require local processing but rather required that the contract of sale include such a condition. It may be significant, in considering the participation-enhancing value of this law, that it was adopted by an agency rather than by the state legislature. The presently governing statute states merely that the contract "terms shall include . . . the sustained yield principle, subject to preference among beneficial uses," Alaska STAT. $\S 38.05 .115$ (1984), and that "[t]he Commissioner may impose . . . terms considered necessary and proper to protect the interests of the state." Id. § 38.05.120.

89 The alternative was processing in Japan, which buys $90 \%$ of Alaska's timber, not in other states. See South-Central Timber Dev., Inc., 467 U.S. at 85-86 n.4. But the Court strongly implied that it would have reached the same result had the market been a purely domestic one with the alternative being processing in another state. See id. at 100 .

80 See id. at 99.

91 The state supplied the raw material (lumber) but not the labor or the capital by which it was processed. Nor had the state tended the trees; they had simply grown on its land.

92 Some commentators have criticized the apparent "anomaly" that state attempts to create trade barriers are per se invalid if the state is acting as a "regulator," but are per se valid if the state is acting as a "participant." See, e.g., Blumoff, supra note 45, at 83-112 (viewing the proprietary exception as an anachronistic product of economic necessity as perceived by state courts in the nineteenth century); Note, Home-State Preferences in Public Contracting: A Study in Economic Balkanization, 58 Iowa L. REv. 576, 583 (1973) (concluding that the "essential validity of the [proprietary/governmental dichotomy] is open to serious question"). But it is precisely the difference in the means employed that calls for different treatment by the courts. See infra notes 104-09 and accompanying text. 
less strain on the commerce clause when it acts as a buyer or seller than as a regulator. One argument, based on original intent, is that although the Constitution was drafted with the goal of ending economic balkanization among the states ${ }^{93}$ the commerce clause is "principally" aimed at private trade, leaving "[s]tates themselves to operate freely in the free market." ${ }^{84}$ There is no evidence, however, that in drafting the commerce clause, the Framers even considered state proprietary activity. ${ }^{95}$ Moreover, federal regulation of interstate trade has expanded beyond any scope the Framers are likely to have contemplated; ${ }^{.6}$ consequently, the Framers' thoughts regarding the limits of state action in the absence of federal regulation should be of limited relevance today.

Perhaps the most frequently offered rationale for treating proprietary activity differently is that when states are acting like private businesses, "evenhandedness" demands that states be treated like private businesses: They should be subject to federal regulation, but otherwise free to discriminate on the basis of state lines. ${ }^{97}$ This rationale makes sense as an argument for allowing state proprietary decisions to reflect the same considerations of price, quality, and even convenience of location that motivate private businesspeople. ${ }^{88}$ One could even argue that these factors will so dominate state proprietary decisions that judicial review is unwarranted. ${ }^{90}$ That point, however, is empirically and theoretically debatable. ${ }^{100}$ In any case, the rationale does not serve as a

${ }^{93}$ See, e.g., H.P. Hood \& Sons, Inc. v. Du Mond, 336 U.S. 525, 533 (1949) (noting Framers' intent to federalize interstate commerce); Eule, supra note 31 , at 430 31 (discussing especially Madison's intent); Stern, supra note 22, at 1337-38 (stating that Framers determined "that the adequate protection of commerce required a complete revision of the structure of government"). But see Regan, supra note 22, at 1114 n.55 (noting that Framers may have been more concerned with state restrictions on international than on interstate trade).

${ }^{94}$ Reeves, Inc. v. Stake, 447 U.S. 429, 437 (1980).

${ }^{95}$ See L. TRIBE, supra note 23, $\S 6-11$ at 432; Varat, supra note 40, at 505.

${ }^{36}$ See supra note 26 and accompanying text.

97 See Wells \& Hellerstein, supra note 65, at 1123; see also Reeves, 447 U.S. at 439 ("[S]tate proprietary activities may be, and often are, burdened with the same restrictions imposed on private market participants. Evenhandedness suggests that, when acting as proprietors, States should similarly share existing freedoms from federal constraints, including the inherent limits of the Commerce Clause.").

${ }_{88}$ See Wells \& Hellerstein, supra note 65, at 1129-30 (acknowledging that "government no doubt has interests that it shares with private enterprise when it enters the market" but cautioning that the market participant exception "should not be permitted under the guise of protecting these interests, to function as a mechanism for according special consideration to the political interests that the government ordinarily pursues").

${ }^{29}$ Cf. American Yearbook Co., 339 F. Supp. at 725 (judicial review "would unduly interfere with state proprietary functions if not bring them to a standstill"); Recent Cases, Constitutional Law, 80 Harv. L. Rev. 1357, 1360-61 (1967) (discussing implications of abandoning the presumption of validity with respect to state proprietary actions).

${ }^{100}$ See Reeves, 447 U.S. at 450 (Powell, J., dissenting) ("A State frequently will 
ground for allowing discrimination so long as it is accomplished by acceptable means, but rather, as a reminder that apparent discrimination may have a nondiscriminatory explanation. ${ }^{101}$ As an argument for allowing states to transact preferentially with their own residents simply because of their residency, however, this reasoning by analogy has properly been criticized as begging the question. ${ }^{102}$ "The very act in question-favoritism of in-state residents without regard to profit-is one that belies reliance on concepts of private property; it is a public act." 103

A better argument is that courts should not intervene precisely because the state is deliberately choosing an "unprofitable" course in restricting its dealings to state residents even though nonresidents may offer better bargains. If the state chooses to subsidize residents by buying from them at inflated prices or by selling them its products at a discount, it merely accomplishes a redistribution that is within its legitimate goals and that (at least theoretically) it could have achieved by other means. Direct grants from the state to some of its residents, even subsidies that help its residents compete in interstate commerce, are not seen as threatening the cohesion of the union; ${ }^{104}$ it is not clear why indirect subsidies would pose any greater danger. ${ }^{105}$ Moreover, the fact

respond to market conditions on the basis of political rather than economic concerns."). But see generally Tiebout, A Pure Theory of Local Expenditures, $64 \mathrm{~J}$. Pol. Econ. 416 (1956) (theorizing that an inverse correlation of capital and taxpayer mobility with jurisdictional size makes local and state governments act more like private businesses than does national government).

101 Thus, this argument seeks to establish states' proprietary conduct as constitutionally permissible under the branch of Pike that upholds nonprotectionist measures marginally burdening interstate commerce in pursuit of legitimate ends. See supra note 82.

102 See Varat, supra note 40, at 506-07 ("The evenhandedness rationale . . begs the question. Why is it important to allow state business to be conducted with the same freedom as private business?").

${ }^{103}$ Id. at 506.

104 Cf. New Energy Co., 108 S. Ct. at 1809-10 (minimal scrutiny given to Indiana ethanol cash subsidy).

${ }^{100}$ Granted, the state's citizens will be less able to monitor hidden than explicit subsidies. $C f$. K. Shepsle \& B. Weingast, Federal Budget Policy in the 1980s 343-67 (discussing how Congress uses hidden subsidies to provide constituents with benefits without alienating nonrecipients, resulting in inefficient spending). But the possibility of obtaining such subsidies, and the need for close involvement in order to prevent them from going to others, is likely to promote participation in state politics, and thus in politics generally. Therefore, the availability of hidden subsidies on the state level may create competition for entrenched national interest groups, arguably strengthening the national political process. Cf. Rapaczynski, supra note 35, at 387-88 (hypothesizing that in a situation in which some union employees have concerns that are not being addressed by the union on a national level, the employees could organize on the local level, influence state legislation, and eventually make their presence felt on the national level, providing some competition for the entrenched union). 
that such policies impose fiscal burdens on states is likely to limit their use and to dampen any cycle of retaliation. ${ }^{108}$ Even without court intervention, state elections and the threat of taxpayer exodus serve as checks.

Such proprietary decisions are also less "coercive" than regulations prohibiting transactions between two private parties. ${ }^{107}$ Because they do not drastically alter the legal status quo, they strike most people as more reasonable, and are less likely to create a cycle of retaliation. ${ }^{108}$ Furthermore, they are not likely to prevent nonresidents from finding alternate suppliers or customers. ${ }^{109}$

"Evenhandedness" toward state proprietary activity has another meaning: the commerce clause should push states neither toward nor away from expanding their public sectors. Professor Varat is concerned that the participant exception may create an incentive to enlarge the public sector. ${ }^{110}$ While he may well be correct that the Constitution should be neutral in this regard, the participant exception clears the way to socialism, or rather to state capitalism, only insofar as it enhances the power of states acting as sellers. In the state purchasing context, however, the exception enables states to privatize traditional state functions without simultaneously loosing the ripple effects that flow from their performance. ${ }^{111}$ Without the exception, states would lose flexibility in reshaping their governments to meet changing needs.

\section{The Labor-Value Theory Applied to Natural RESOURCES}

The labor-value theory discussed above was hardened into doctrine by Reeves, Inc. v. Stake. ${ }^{112}$ In Reeves, the Court held that South Dakota was entitled to keep cement produced by a state-owned factory because

[c]ement is not a natural resource, like coal, timber, wild game, or minerals. It is the end product of a complex process

${ }^{106}$ See Regan, supra note 22, at 1194 (noting that the "very fact that spending programs involve spending . . . makes them less likely to proliferate than measures like tariffs").

${ }_{107}$ See id.

108 See id.

108 See id. at 1195.

110 See Varat, supra note 40, at $530 \mathrm{n} .175$ (concluding that such a bias is tolerable because the Constitution contemplates state freedom to choose public sectors of various sizes and because other features of our society will preclude rampant socialism).

11 See American Yearbook Co. v. Askew, 339 F. Supp. 719 (M.D. Fla.), affd mem., 409 U.S. 904 (1972).

112447 U.S. 429 (1980). 
whereby a costly physical plant and human labor act on raw materials. South Dakota has not sought to limit access to the State's limestone or other materials used to make cement. ${ }^{113}$

The term "natural resource" connotes at least two meanings. It can mean either a good produced by nature with minimal social investment, or a tangible good physically similar to items in the first category but requiring significant investment, either to produce it or to make it available for consumption. A tree growing in virgin forest belongs to the first category, what this Comment will call "raw" natural resources. A tree grown in Brooklyn, however, was probably tended by someone.

Before the turn of the century, the Supreme Court adhered to the common law rule that raw natural resources such as wild game belonged to the state as trustee for present and future inhabitants. ${ }^{114}$ With the growth of an integrated and industrial national economy, this rule came to be seen as anachronistic. Protectionist laws transferred control over the alienability of resources from entrepreneurs who had invested, or wished to invest in their exploitation, to states that were by mere fortuity located on resource-rich land. Thus, the Court held in a series of cases in the early 1900s that a state may not "giv[e] a preference to its inhabitants in the enjoyment of its [merely] natural advantages."11s The lone fact that the Paleozoic era deposited more coal under Pennsylvania than under New Jersey gives Pennsylvanians no greater claim to such coal's use. ${ }^{116}$ This conception of natural resources continues in force. Recent decisions striking down protectionist laws based on the mere fact that a state declares "ownership" over wild

113 Id. at 443-44 (citations omitted).

114 See, e.g., Geer v. Connecticut, 161 U.S. 519, 529 (1896) (noting that the " "ownership of wild animals . . . is in the State . . in its sovereign capacity as the representative and for the benefit of all its people in common" (quoting State v. Rodman, 58 Minn. 393, 400, 59 N.W. 1098, 1099 (1894)); McCready v. Virginia, 94 U.S. 391,394 (1876) (explaining that each state owns the tidewaters within its jurisdiction and the fish they contain).

115 Pennsylvania v. West Virginia, 262 U.S. 553, 602 (1923) (Holmes, J., dissenting) (characterizing the majority's holding); see Toomer v. Witsell, 334 U.S. 385, 403, 406 (1948) (finding unconstitutional a South Carolina statute requiring out-of-state shrimp boats operating in South Carolina waters to pay higher licensing fees and to process their catch in South Carolina); Foster-Fountain Packing Co. v. Haydel, 278 U.S. 1, 13 (1928) (invalidating a similar Louisiana law); Pennsylvania v. West Virginia, 262 U.S. at 595-600 (striking down West Virginia's attempt to give preference to domestic consumers of natural gas over out-of-state users); West v. Kansas Natural Gas Co., 221 U.S. 229, 262 (1911) (finding unconstitutional an Oklahoma law prohibiting foreign corporations from transporting natural gas out of the state).

${ }_{118}$ Cf. West, 221 U.S. at 255 (arguing that were the Court to uphold the statute in question, then "Pennsylvania might keep its coal, the Northwest its timber, the mining states their minerals"). 
game or raw natural resources found within its borders, fit comfortably within the conception's rationale. ${ }^{117}$

Some "natural" resources, however, exist only because significant efforts have been invested in sustaining and preserving them. In Baldwin v. Fish $\&$ Game Commission, ${ }^{118}$ for example, the Court upheld a state law that discriminated against nonresidents in granting permits to hunt elk after recognizing that "wild" elk still roamed Montana largely because the state had invested in their preservation by employing rangers and regulating hunting. ${ }^{119}$

This distinction is growing in importance, because, as the American frontier continues to close, the natural resources that remain increasingly owe their existence to some form of human investment. The Constitution should perhaps contain a positive bias toward protection of future generations in order to ensure the longevity of the union. ${ }^{120}$ In any case, the Constitution should not push states away from investing

117 See, e.g., Sporhase v. Nebraska ex rel. Douglas, 458 U.S. 941, 957-58 (1982) (invalidating Nebraska's attempt to restrict ground water exportation by requiring reciprocity with the exporting state); New England Power Co. v. New Hampshire, 455 U.S. 331, 333-40 (1982) (invalidating New Hampshire's attempt to restrict use of energy generated by the Connecticut river because New Hampshire "owned" the river); Hughes v. Oklahoma, 441 U.S. 322, 325 (1979) (invalidating Oklahoma's attempt to restrict minnow exports, and thereby overruling Geer).

118436 U.S. 371 (1978). Baldwin was a privileges and immunities clause, see U.S. CoNST. art. IV, $\S 2$, cl. 1, rather than a commerce clause case. However, the doctrine appears to have force in the commerce clause area as well. See Commonwealth Edison Co. v. Montana, 453 U.S. 609, 614-29 (1981); see also Hellerstein, Hughes v. Oklahoma: The Court, the Commerce Clause, and State Control of. Natural Resources, 1979 S. Cr. REv. 51, 89 (noting that the Virginia oyster beds at issue in McCready "should be treated differently from unowned resources .... If the States [sic] had expended large sums of money to develop, manage, and cultivate oyster beds located in state waters, one might regard the entire enterprise as a "statewide oyster "farm" subsidized by the State, to which access might reasonably be limited" (footnote omitted)).

This Comment does not directly address the implications of privileges and immunities clause doctrine for state attempts to preserve natural resources, primarily for the sake of simplicity and also because challenges to such state laws typically are launched by corporations. Under longstanding precedents, "corporate entit[ies] . . . cannot claim the protection of article IV's privileges and immunities clause." L. TRIBE, supra note $23, \S 6-2$ n.3.

${ }_{119}$ See Baldwin, 436 U.S. at 375-76. It seems to be irrelevant for commerce clause analysis whether the resource at issue is wanted for hunting or for some other more "essential" use. See Commonwealth Edison Co., 453 U.S. at 614-29 (upholding Montana's severance tax on coal against dormant commerce clause attack, despite the national importance of that resource). But see Pennsylvania v. West Virginia, 262 U.S. at 601 (Holmes, J., dissenting) (suggesting that the natural gas the state sought to preserve was more important than the damaged citrus fruits subject to state regulation sustained in Sligh v. Kirkwood, 237 U.S. 52 (1915)).

${ }^{120}$ More tenuously, it could also be argued that future generations deserve protection in today's decisions as a "discrete and insular" interest group. See United States v. Garolene Prods. Co., 304 U.S. 144, 152-53 n.4 (1938). 
in preserving their natural resources and toward investing in their exploitation. Yet this perverse incentive is precisely the result if the Reeves holding (that states may retain the benefits of exploiting their natural resources) stands, while states are barred from reaping the benefits of their conservation efforts.

In Baldwin, the state investment in elk preservation took the form of monetary outlays. ${ }^{121}$ The monetary nature of the investment is not central to the investment-value rationale; a state whose citizens each devoted one day per year to elk conservation work would be at least as entitled as those of Montana (who paid through taxes) to localize elk use. $^{122}$

A much harder question would be posed by a state claiming that its past frugality in forestalling exploitation is responsible for a resource's current availability. ${ }^{123}$ Applied indiscriminately, such a "thrift" exception would swallow the rule limiting protectionism to state-created goods. In Sporhase v. Nebraska, for example, Nebraska, although it was not responsible for the rain, had encouraged water conservation and was thus partly responsible for the level of the aquifer. ${ }^{124}$ On the other hand, the same notions of equity and encouragement of investment that underlie the general labor-value rule argue for allowing states to reap the benefit of their past thrift. One solution to this dilemma is to apply the "thrift" exception only when the state, in order to encourage conservation, has purposefully encouraged or coerced its residents into changing their practices from some preexisting or national norm.

\section{Application to Solid Waste}

\section{A. Disposal Capacity as a State-Created Resource}

In a two-word parenthetical, the Reeves Court implicitly contrasted the export of work product with what it had characterized as the effective export of undeveloped open space in Philadelphia $v$. New

121 See Baldwin, 436 U.S. at 389.

122 It has been argued that the restraint necessitated by direct fiscal outlays is an important safeguard limiting the market participant exception. See Regan, supra note 22 , at 1194-95. Citizens' resistance to changing their lifestyle to meet state needs, however, is an equivalent, if not much stronger, restraint.

${ }^{123}$ This is a question on which Regan explicitly reserves judgment. See id. at 1203 (speculating that a state's residents "may be entitled to benefit specially from a state policy of general nondevelopment that they specially bear the opportunity costs of').

124 See Sporhase v. Nebraska ex rel. Douglas, 458 U.S. 941, 957-58 (1982) (invalidating Nebraska's attempt to restrict ground water exportation by requiring reciprocity with the exporting state); id. at 955. 
Jersey. ${ }^{125}$ The Court had no cause then to rethink the nature of the disposal market. But today, far more than in 1978, when a state accepts garbage and effectively exports the right to use landfill space, it exports much more than the raw undeveloped natural resource value of the land. If the state pays for the operation of a disposal facility, it also exports services, including compliance with increasingly stringent environmental regulations. ${ }^{126}$ Although the value of those services may be most apparent where the disposal is by capital-intensive incineration, ${ }^{\mathbf{1 2 7}}$ it is also substantial when disposal is by the far more common method of landfilling. ${ }^{128}$

Further, regardless of who operates the disposal facility, it is the residents of the receiving state who bear the social costs of waste acceptance. These costs include the necessity of increased recycling efforts by local businesses and residents; ${ }^{129}$ health risks and environmental degradation; ${ }^{\mathbf{1 3 0}}$ and eventually a divisive and expensive siting procedure for

${ }^{125}$ Compare Reeves, Inc. v. Stake, 447 U.S. 429, 443 (1980) (characterizing "landfill sites" as natural resources) with Philadelphia v. New Jersey, 437 U.S. 617, 628 (1978) (finding it a "difference . . . without consequence" that the scarce natural resource at issue, the state's remaining landfill space and open lands, did not physically move as an article of commerce).

${ }^{126}$ See infra note 218 and accompanying text.

${ }^{127}$ See Florini, Issues of Federalism in Hazardous Waste Control: Cooperation or Confusion?, 6 HaRv. ENvTL. L. REv. 307, 334 (1982) (noting that a "sophisticated hazardous waste facility, such as an incinerator" is particularly likely to pass the Reeves "costly physical plant" test).

${ }^{128}$ See Lefrancois v. Rhode Island, 669 F. Supp. 1204, 1211-12 (D.R.I. 1987) (disposing of the Reeves Court's parenthetical reference to Philadelphia $v$. New Jersey by defining the relevant market as the market for landfill services, rather than landfill sites); County Comm'rs v. Stevens, 299 Md. 203, 216, 473 A.2d 12, 19 (1984) (characterizing market as landfill services rather than sites).

128 The leading legislative proposals to increase recycling are expensive; they are economical only because their costs are offset by disposal cost savings. See, e.g., PENNsylvania Dep't. of Environmental Resources, Bureau of Waste Management, Curbside Recycling in Pennsylvania 2 (1985) (estimating curbside recycling collection costs at $\$ 23.18$ per ton, $\$ 4.69$ per ton more than the resale value of the materials collected, but $\$ 8.28$ per ton less than the direct cost of disposal); Memo from Charles Greenwalt, Director, Policy Development and Research Office, to Senator Michael Fisher, Chairman, Pennsylvania Senate Environmental Resources and Energy Committee, on Costs and Benefits of Bottle Bill Legislation 66-67 (Jan. 29, 1987) (estimating yearly costs of handling returnable beverage containers at $\$ 201.2$ million) (on file with the University of Pennsyluania Law Review).

${ }^{130}$ See 1 U.S. Environmental Protection Agency, Office of Solid Waste and Emergency Response, Solid Waste Disposal in the United STATEs 16-34 (1988) (reviewing the significant adverse environmental effects of municipal solid waste landfills); id. at 17-19 (finding "little difference in the location, design, and operation of newer municipal solid waste landfills versus older landfills"); id. at 34-40 (reviewing the scanty data on environmental impacts of Industrial Subtitle D facilities, such as industrial landfills and mining waste piles, and finding "cause for concern"); see also Brief for Appellee at 37-40, Philadelphia v. New Jersey, 437 U.S. 617 (1978) (No. 77-404) (arguing that landfills necessarily damage aesthetic and envi- 
additional waste disposal facilities. ${ }^{131}$ The garbage-receiving state essentially exports a third benefit by enabling its neighbor to avoid those costs. It can do so because its residents have worked and will continue to work as a polity to reduce waste production, save open space for landfilling, absorb and mitigate the health and environmental costs of waste acceptance, and make a hard choice on siting.

A state never "owns" this ability in the same way that it can own legal title to the piece of land being polluted. But if a state's declaration that it owns a resource does not prove that it has earned it, ${ }^{132}$ the converse should also be true: That a resource is too intangible for a state to "own" does not prove that the state did not work to create it. ${ }^{133}$

\section{B. Considerations Arguing For Upholding State Laws}

The solid waste context illustrates the need for allowing states to capture the benefits of their investments. Suppose a state (call it Sylvania) can neither prevent its neighbor Urbana from using its landfills, nor recover compensation for the social costs it thereby incurs. Suppose further that the inverse is also true. Urbana will be dissuaded from working to reduce its waste production, because much of the benefit of this reduction would flow to Sylvania. Urbana will not want to build its disposal capacity for the same reason. Sylvania will soon be faced with the need to either increase its disposal facilities or reduce its waste production. But it will probably do neither. Instead, it will send more waste out of state, to Urbana or anywhere else disposal capacity remains. The result of this cycle is under-investment in waste reduction or facility siting, or as is most likely in this politically-charged context, under-investment in both. ${ }^{134}$

Beyond this threshold labor-value argument, additional reasons

ronmental values because even if new technologies to prevent groundwater leaching prove successful in the long run, all landfills produce dangerous gases); Shabecoff, Ashes of Garbage are Found Toxic, N.Y. Times, Nov. 26, 1987, at A2, col. 1 (reporting EPA findings that ash from garbage incineration contains significant levels of toxic metals); Shabecoff, Tighter U.S. Rules Proposed for Municipal Incinerators, N.Y. Times, July 2, 1987, at A16, col. 1 (citing an EPA study demonstrating that pollution from garbage incinerators can cause cancer and other illnesses).

131 See Glaberson, Coping in the Age of "Nimby," N.Y. Times, June 19, 1988, at C1, col. 2 (describing residents' opposition to attempts to locate waste disposal sites in their communities).

132 See supra note 117 and accompanying text.

${ }^{133} C$. infra notes 168-74 and accompanying text (discussing statement in Commonwealth Edison Co. v. Montana, 453 U.S. 609, 627 (1981), that a state may impose excise taxes for the service of providing "the advantages of a civilized society").

${ }^{134}$ Cf. Florini, supra note 127, at 324-27 (providing a fuller discussion of this "reverse commons problem" in the context of hazardous wastes). 
counsel loose judicial regulation of states' responses to the solid waste crisis. As discussed above, courts facing a dormant commerce clause issue should emulate a hypothetical congress preoccupied with preserving a dynamically functioning federalist system. ${ }^{135}$ There are a number of reasons such a congress would give states a loose rein in dealing with solid waste.

First, localizing solid waste policy decisions will promote popular participation in their making. ${ }^{\mathbf{1 3 6}}$ It may be that people participate more in smaller political units in which they have greater proportionate influence, ${ }^{137}$ the proposition certainly seems to apply to issues of waste disposal. Thousands of local and statewide organizations have sprung up over the past two decades, for example, to protest disposal facilities. While often derided as based on mere "nimby" (not in my backyard) thinking, such participation has value. Without broad public participation, the political process will be skewed toward protection of large waste producers and handlers, who have a larger stake in the outcome. Thus, broad political participation can lead to decisions more in line with the interests, not only of the state's citizenry, but of the nation. ${ }^{138}$

Moreover, local participation is vital to legitimizing the decision. Legitimacy in turn is vital to the success of source reduction measures, which may require some lifestyle changes. It will also lower the transaction costs of facility siting. The opportunity to participate also has its own intrinsic value in that it upholds the dignity of citizens. Indeed, local participation may protect that value better than participation restricted to national politics.

Second, waste disposal and processing is an area in which experimentation by the states is devoutly to be wished. ${ }^{139}$ Recycling, in partic-

135 See supra text accompanying notes 22-41.

${ }^{138}$ See Rapaczynski, supra note 35, at 395-408.

137 See Advisory Commission on Intergovernmental Relations, Citizen Participation in the American Federal System 91-96 (1979) (finding that while substantial citizen participation occurs at every level of American government, the frequency and breadth of participation is higher at more local levels).

${ }^{138}$ See Ethridge, Procedures for Citizen Involvement in Environmental Policy: An Assessment of Policy Effects, in Citizen Participation in Public Decision Making 115, 128-30 (J. DeSario \& S. Langton eds. 1987) (concluding that opening the federal bureaucracy to participation simply "create[s] somewhat better access for interests already influential"; only "broad-based mobilization" will "create genuine public influence").

139 See New State Ice Co. v. Liebmann, 285 U.S. 262, 311 (1932); see also Reeves, Inc., 447 U.S. at 441 (noting that wielding the dormant commerce clause sparingly fosters "effective and creative programs for solving local problems"); Hughes v. Alexandria Scrap, 426 U.S. 794, 816 (Stevens, J., concurring) (arguing that the commerce clause should not "inhibit a state's power to experiment with different methods of encouraging local industry"). But cf. Note, The Disposition of State-Owned Resources Under the Commerce Clause, 21 Hous. L. REv. 533, 545 n.92 (interpreting 
ular, involves invention and the development of new institutions. ${ }^{140}$ Much of the apparent economic efficiency of a national free-trade-zone policy comes from shifting waste disposal from regions with diminished capacity to regions with greater capacity. While at any given moment this will be the most macro-efficient disposal pattern, it will tend to result in postponing the "garbage crisis" until it is encountered nationwide. The costs of learning how to deal with disposal problems will then be much larger and will be felt nationwide instead of being confined to a few states. Moreover, because measures such as household separation of recyclables from trash and packaging reform may require significant alterations of lifestyle, legislatures and Congress will be very reluctant to pass such measures if their efficacy has not been proven in practice. There are reasons to desire and expect eventual federal regulation, but it will be more effective if based on states' experience.

Third, the costs incurred when a state accepts waste fall unevenly throughout the state and are valued differently by different people. Whatever decision the state makes, including the decision not to sell disposal capacity to nonresidents at any price, the state unavoidably offends some of its residents. If only because such strain and disaffection within the state create problems for national political unity as well, the state should be free to seek accommodation of its residents' divergent interests. ${ }^{141}$ And because any decision is likely to have redistributive effects, including intergenerational redistribution, the state is in a better position to make these decisions than is the federal government.

A fourth possible reason is more problematic. Our hypothetical congress might be tempted to minimize political strain by allowing protectionist barriers simply because many citizens feel differently about bearing the social costs of waste when it comes from outside the political community. ${ }^{142}$ This feeling may go beyond a reasonable desire for

these quotations as suggesting that "[t]he Supreme Court seems inclined to give the states wider latitude when state actions are of local rather than national importance").

110 Federal legislative and executive officers may be in a better position to benefit from successful innovations and hence may be less risk-averse than state and local officials. See Rapaczynski, supra note 35, at 408-414; Rose-Ackerman, Risk-Taking and Reelection: Does Federalism Promote Innovation, 9 J. LEgal STUD. 593, 614-16 (1980). That possibility argues for allowing the federal government full preemption power. It does not, however, argue for limiting what innovation state and local officials do undertake in the face of federal silence.

${ }^{141}$ The Carolene Products argument that the courts must protect the interests of nonresidents, see supra notes 73-111 and accompanying text, loses what force it may have when a block of residents adequately represents nonresident interests.

142 See D. Morell \& C. Magorian, Siting Hazardous Waste Facilities: Local Opposition and THE MYTH of PreEmption 74 (1982) (reporting a Duke University poll of North Carolina residents: "[O]nly 7 percent of the respondents said they approved of allowing wastes generated out of state to be disposed of in their 
fair compensation and become parochialism. There is a difference between states taking into account fiscal effects, such as increased siting costs, that result from such parochialism, and counting injured parochial sentiments themselves as a cost. ${ }^{143}$ While the actual Congress is free to do so, ${ }^{144}$ courts acting as a hypothetical congress should hesitate to give the latter legal voice.

\section{G. Ways to Keep Disposal Capacity}

States can take many steps to reduce their waste production, and thereby (unless other states rush into the vacuum) save disposal capacity, without raising significant constitutional issues. ${ }^{145}$ The dormant commerce clause should also allow states to reserve disposal rights to their own citizens using means commensurate to the degree that the value of those rights was created by the efforts of the state and the forbearance of its citizens. ${ }^{146}$ Allowing protectionist barriers is one solution to the problem of externalized social costs. But it must be noted that it is not the only solution. Protectionist barriers have monetary and environmental costs of their own. ${ }^{\mathbf{1 4 7}}$ In any case, the availability of al-

county. About 38 percent said they would be willing to allow wastes from within the state, and 49 percent said they would only accept wastes from within their county."); Sandman, Getting to Maybe: Some Communications Aspects of Siting Hazardous Waste Facilities, 9 SETON Hall LEg. J. 437, 454-55 (1985) (discussing same poll). It is reasonable to assume that many citizens hold similar preferences against imported solid waste. Cf. Barden, Garbage is One Thing, but Garbage from New York? Forget It, N.Y. Times, Feb. 12, 1989, at A26, col. 2 (reporting that constituents' adverse reaction to the prospect of garbage importation, particularly from AIDS-plagued New York, forced officials of Benton, Ark., to reject a lucrative waste-acceptance contract).

${ }_{143}$ Cf. Palmer v. Thompson, 403 U.S. 217, 225 (1971) (upholding city's decision to close its municipal swimming pools after they had been ordered desegregated on the ground that the city had reasonably concluded that the pools "could not be operated safely and economically on an integrated basis").

144 See supra note 10 (noting that Congress in its treatment of low-level radioactive waste disposal implicitly recognized parochial sentiments).

${ }_{145}$ The most widely-discussed measures are curbside separation and container deposit legislation to promote recycling, see supra note 129 and accompanying text, and packaging reform to limit discards, see, e.g, Lai \& Selke, The Role of Packaging in the Trash Crisis, 1 V.I.E.W. Proc. 151 (1988). Such exercises of the states' police powers do not discriminate against nonresidents; therefore, under the standard Pike test, see supra note 82 and accompanying text, they are presumptively legitimate. See Minnesota v. Clover Leaf Creamery Co., 449 U.S. 456, 470 (1981) (upholding a ban on the sale of milk in plastic nonreturnable containers); American Can Co. v. Oregon Liquor Control Comm'n, 15 Or. App. 618, 627-47, 517 P.2d 691, 696-705 (1973) (upholding container deposit law).

${ }^{146}$ Hellerstein, supra note 118 , at 91 , implies that the technique used for holding onto resources should be proportionate to the degree of ownership, on some kind of sliding scale.

${ }_{147}$ For example, some states may as a matter of geography have few environmentally sound disposal sites. All else being equal, it is environmentally preferable for such 
ternate means must be considered; because the market participant exception includes a means test, the availability of alternate means may argue against applying it.

Absent federal regulation, states seeking to keep state-created disposal capacity have at least five alternatives. First, they may in some circumstances completely blockade exogenous waste. Second, they may follow Rhode Island's example, and manage all disposal operations themselves, while refusing to admit exogenous waste into state-operated facilities. Third, they may charge for the disposal of waste within their borders, by raising tipping fees at state-run facilities and by taxing private landfill operators. Fourth, they may refuse waste from states with weaker recycling programs. And fifth, they may allow or require each county in the state to refuse out-of-county waste. The limits of these alternatives demand further exploration. So, briefly, does a sixth possibility: federal regulation.

The aim of this brief survey is not to provide conclusive answers concerning the constitutionality of these various arrangements. The discussion above has sought to advance a general perspective on the dormant commerce clause, not a fully developed theory capable of such application. Rather, the aim is to illustrate the types of questions that the process-enhancing perspective may soon be called upon to frame, and to hazard some very preliminary responses.

\section{A Complete Ban on All Solid Waste Importation}

\section{a. State-Owned Facilities}

When the state not only absorbs the social costs of a landfill but also owns the land and operates the landfill, it should be allowed to withhold landfill space entirely from residents of other states. ${ }^{148} \mathrm{As}$ argued above, the labor-value theory alone is enough to justify states in

states to export their waste. Furthermore, it would be less costly to divide waste management districts by metropolitan "wasteshed" regions than by state line. See Comment, State Embargo of Solid Waste: Impermissible Isolation or Rational Solution to a Pressing Problem?, 82 Dick. L. REv. 325, 330 \& n.29 (1978). It was for the latter reason that the EPA intervened as amicus curiae and sided with the appellants in Philadelphia v. New Jersey. See Lecture by Joseph Manko, former General Counsel to EPA Region III (Feb. 8 1989); see also Jurisdictional Statement at A102-A105, Philadelphia v. New Jersey, 430 U.S. 141 (1977).

${ }_{148}$ See Comment, State Immunity from Dormant Commerce Clause: Extension of the Market-Participant Doctrine from State Purchase and Sale of Goods and Services to Natural Resources, 25 NAT. Resources J. 515, 545 (1985) (arguing that "the state has little difficulty in establishing ownership if the natural resource is on state public lands and subject to state extraction"). 
refusing nonresidents access to state-owned disposal facilities. ${ }^{\mathbf{1 4 8}}$

But what if the state runs every facility within its territory? This question was before the courts in Stevens, Shayne Bros., and Lefrancois, but those courts were able to avoid the inquiry by noting the availability of procedures for the licencing of new, private landfills. ${ }^{150}$ Suppose, however, that a state either repealed its licencing provisions, or its past practice demonstrated its unwillingness to licence private facilities. Should there be a "monopoly exception" to the market participant exception? Absent an emergency, no. The blockading state has no monopoly on the inputs necessary to create disposal capacity elsewhere. Other states may obtain those inputs and dispose of their own wastes. ${ }^{151}$ When the state seeking to export waste has neither time nor alternatives, however, the immediate threat to the public health might entitle it to an injunction. ${ }^{\mathbf{1 5 2}}$

\section{b. Private Facilities}

The "market participant" exception may sometimes justify withholding private landfill space as well. If the social costs of waste disposal are sufficiently large, the citizens' input in accepting them may completely overshadow the land and service inputs of even a private landfill owner.

When Philadelphia v. New Jersey was decided, this factual condition was probably not met. It may or may not be today. If population density and the demand for environmental quality both continue to rise, however, it will certainly be met at some future point. Even if the la-

149 Lefrancois v. Rhode Island, 669 F. Supp. 1204 (D.R.I. 1987) provides a particularly strong precedent for this proposition. A milder means of keeping landfill capacity was already in place before the state banned importation, yet the ban was upheld. See supra note 20.

${ }^{150}$ See Lefrancois, 669 F. Supp. at 1210-12; Shaye Bros., Inc. v. District of Columbia, 592 F. Supp. 1128, 1134 (D.D.C. 1984); County Comm'rs v. Stevens, 299 Md. 203, 214, 473 A.2d 12, 19 (1984). The issue might have been present but the plaintiffs appear not to have raised it in Kavanagh v. London Grove, $33 \mathrm{~Pa}$. Commw. 420, 422-23, 382 A.2d 148, 149-50 (1978), aff d by an equally divided court, $486 \mathrm{~Pa}$. 133, 404 A.2d 393 (1979) (upholding a zoning ordinance barring privately owned landfills against a constitutional attack apparently based solely on the fifth and fourteenth amendments).

151 See Varat, supra note 40, at 539 (arguing that a state with monopoly power over a resource has an equity obligation to share it with nonresidents, but that this obligation may disappear if the resource could be duplicated in the other state).

${ }_{152}$ Kavanagh, $486 \mathrm{~Pa}$. at 135, $404 \mathrm{~A} .2 \mathrm{~d}$ at 394 (Roberts, J., voting to affirm), suggests that municipalities might be allowed to zone for only publicly-owned facilities because these facilities are more likely to prevent environmental damage and to remain available to pay for closure. While the first distinction can be argued, the second will likely be obviated by proposed federal regulations. See infra note 218 and accompanying text. 
bor-value argument alone fails fully to justify a total blockade, the value of state variation, participation, and adjustment of local interests might tip the balance in its favor. When continued waste importation will create a critical near-term shortage of disposal capacity and thereby threaten public health while new capacity is sought or built, of course, states' powers are even greater. ${ }^{153}$

\section{Monetary Compensation}

If Sylvania charged a fee for the disposal of waste within its borders greater than the land and service costs of disposal, it would induce its Urbanian neighbors to dispose of their own garbage and reduce their waste production. ${ }^{154}$ Such state efforts to obtain monetary compensation for receiving waste are constitutionally permissible, and states are beginning to use them. ${ }^{155}$ If we are willing to accept that the values destroyed by solid waste may be given a dollar price, such a fee could fully compensate Sylvania for the loss of those values. Further, the monies received could be targeted to those most affected by the disposal facility. Higher disposal costs, however, make illegal dumping more likely. ${ }^{168}$ Collecting them also involves administrative costs. ${ }^{157}$

${ }^{153}$ See Borough of Glassboro v. Gloucester County Bd., 100 N.J. 134, 149, 495 A.2d 49, 57, cert. denied, 474 U.S. 1008 (1985); see also Comment, Trial Court Order Barring the City of Philadelphia from Dumping Solid Waste at Kinsley Landfill is not an Unconstitutional Burden On Interstate Commerce, 17 RUTGERS L.J. 363, 37379 (1986).

164 See generally Garbage and the Commerce Clause: New Approaches for an Effluent Society, 106 N.J.L.J., Oct. 30, 1980, at 4, 4 (editorial) (suggesting that New Jersey raise landfill fees to reduce waste importation).

${ }_{105}$ See, e.g., N.J. STAT. ANN. § 13:1E-28(a)-(b) (West Supp. 1988) (imposing tipping fees starting at $\$ 1.50$ per ton of solid waste in 1985 , now $\$ 4.65)$; R.I. GEN. LAws $\$ 23-19-13(\mathrm{~g})$ (1986) (imposing fees of $\$ 8$ per ton in 1986, increasing to $\$ 13$ in 1990 and at a rate of $7.5 \%$ annually thereafter); $1988 \mathrm{~Pa}$. Legis. Serv. 414, 432 (Purdon) (to be codified at 53 PA. Cons. STAT. ANN. $\$ \S 4000.701$ (a), 4000.1310(b) (Purdon)) (imposing recycling and host municipality benefit fees totaling $\$ 3.00$ per ton of solid waste); see also sources cited supra note 6 (surveying state responses to the solid waste crisis); infra note 205 and accompanying text (noting that New Jersey imposes a tax on the importation of solid waste into a county solid waste management district).

${ }^{156}$ See, e.g., Hanley, Hauling Costs Soaring, Jerseyans Turn to Dumping Trash Illegally, N.Y. Times, Mar. 18, 1988, at A1, col. 5 (reporting that illegal dumping in New Jersey is on the rise along with tipping fees). See generally Calabresi \& Melamed, Property Rules, Liability Rules, and Inalienability: One View of the Cathedral, 85 HARv. L. REv. 1089, 1110 (1972) (arguing that enforcement costs may make a theoretically efficient rule inefficient in practice).

${ }^{157}$ For those states with caps on the absolute size of their budget, spending more state money on waste regulation and facility siting, means that the state has to limit other services even if it earns revenue for its efforts. This argument is less compelling, however, given that the state can always increase its budget ceiling. 


\section{a. Raised Fees at State-Owned Facilities}

Increased tipping fees at state-owned facilities should raise few questions. If state ownership confers the right to refuse altogether to accept exogenous waste, ${ }^{158}$ then surely the state has the lesser power to set any price the market will bear. In other words, state-owned disposal capacity is protected by a property rule under which the state legislature can decide whether to transfer it and on what terms, ${ }^{\mathbf{1 5 9}}$ rather than by a liability rule under which nonresidents may purchase it at a judicially-determined price. ${ }^{160}$ That states acting as market participants hold their wares under a property rule is precisely what the Court held in Reeves, Inc., v. Stake. ${ }^{161}$

Even if the state charges nonresident waste producers more than it charges residents, nonresidents are either paying more than the total costs to the state and its residents of accepting their waste, or they are not. If the latter, the state's taxpayers are subsidizing waste disposal and may legitimately reserve most of that subsidy to residents. ${ }^{162}$ If the former, the state is subject to competition from other sources of disposal capacity. ${ }^{163}$ If it does not lower its price, it is choosing to forgo a profitable transfer for the benefit of its future inhabitants-a decision unlikely to harm the political fabric of the union, particularly because the present taxpayers' and voters' self-interest lines up with that of nonresidents.

\section{b. Nondiscriminatory Excise Taxes on Private Operators}

Excise taxes on private landfill operators should also be allowed. Under the four-part test established in Complete Auto Transit, the court will "sustain[] a tax against Commerce Clause challenge when the tax is applied to an activity with a substantial nexus with the taxing State, is fairly apportioned, does not discriminate against interstate

${ }^{158}$ See Lefrancois, $669 \mathrm{~F}$. Supp. at 1212 (holding that a state acting as a participant in the landfill services market may refuse to sell disposal capacity to nonresidents).

158 This property rule is subject, however, to congressional limitation. See infra notes $212-24$ and accompanying text.

${ }_{160}$ See generally Calabresi \& Melamed, supra note 156, at 1106-10 (analyzing the difference between property rules and liability rules).

181447 U.S. $429,446-47$ (1980).

162 While its litigation strategy precluded making this argument, New Jersey seems to have subsidized waste disposal in the years before Philadelphia v. New Jersey. See Note, The Commerce Clause and Interstate Waste Disposal: New Jersey's Options After the Philadelphia Decision, 11 RuT.-CAM. L.J. 31, 38 \& nn.66-68 (1979) (noting that political pressure from New Jersey municipalities had kept disposal costs in New Jersey artificially low when compared to New York and Pennsylvania).

${ }_{163}$ This competition is increasing as the costs of disposal rise relative to the costs of transportation. See sources cited supra note 5. 
commerce, and is fairly related to the services provided by the State."164 Waste disposal provides a more than substantial nexus with the receiving state; ${ }^{165}$ a fair apportionment issue is unlikely; ${ }^{168}$ and by hypothesis, the excise tax considered here applies to all waste deposited at the landfill on a nondiscriminatory per-ton or other basis. ${ }^{167}$ The requirement that taxation bear a "fair relation" to services provided by the state, however, is somewhat more problematic.

A narrow construction of "services" might limit taxation to such direct costs as the marginal increase in the state environmental agency's budget necessitated by the need to regulate a larger volume of waste. ${ }^{168}$ Under Commonwealth Edison Co. v. Montana, ${ }^{168}$ however, "services" is defined very broadly. The state may demand compensation for indirect services such as its ongoing efforts to provide "police and fire protection, the benefit of a trained work force, and 'the advantages of a civilized society. "170 Had the state not provided these services yesterday, the taxed commerce would be impossible today; without continuing efforts, it would become impossible tomorrow. This rubric is broad enough to encompass the costs ${ }^{171}$ of siting disposal facilities, developing recycling programs, and mitigating health and aesthetic problems occasioned by waste acceptance. ${ }^{172}$ Whether the tax may also reflect costs borne by citizens uncompensated by the state treasury, such as the costs of complying with recycling laws, presents difficult theoretical issues. Practically, however, courts will grant the state such great deference in assessing the value of the services it provides that the state may charge as much as it wants. ${ }^{173}$ The reasons for deference cited by the Com-

${ }_{164}$ Complete Auto Transit, Inc. v. Brady, 430 U.S. 274, 279 (1977).

${ }_{165}$ When the disposal is by landfilling, the nexus is physical.

${ }^{166}$ A fair apportionment issue conceivably could arise if a producer claimed she had already paid her own state for costs associated with the anticipated but unrealized landfilling of the wastes in that state.

${ }_{167}$ See infra notes $185-88$ and accompanying text.

${ }_{168}$ Cf. Commonwealth Edison Co. v. Montana, 453 U.S. 609, 620 n.10 (1981) (summarizing appellants' attempt to calculate a constitutional ceiling on coal excise taxes from the net marginal cost to the state government per ton of coal mined).

169 Id.

170 Id. at 627 (citing Exxon Corp. v. Wisconsin Dep't of Revenue, 447 U.S. 207, 228 (1980) (quoting Japan Line, Ltd. v. County of Los Angeles, 441 U.S. 434, 445 (1979))).

${ }_{171}$ See supra notes $125-38$ and accompanying text.

172 Under the broadest reading of Commonwealth Edison, any tax rate is acceptable so long as it is proportional to nonresidents' contact with the taxing state and the tax is zero when the activity is zero. See Commonwealth Edison, 453 U.S. at 626-29. In other words, if the tax can be graphed as a straight line with the equation $y=m x+b$, ( $m$ equals the tax rate, $x$ equals the nonresident taxpayer's contact with the state, $b$ is the tax when $x=0$, and $y$ is the tax thus calculated), then the tax is constitutional if $b=0$, no matter how steep $m$ may be.

${ }^{173}$ See id. at 627 (asserting that "the appropriate level or rate of taxation is essen- 
monwealth Edison Court apply to states' assessments of the value of their waste acceptance services. ${ }^{174}$

\section{c. Discriminatory Taxation}

Intrastate transportation of solid waste has costs of its own, ${ }^{175}$ and states are entitled to recover them. ${ }^{176}$ In many geographical configurations, exogenous waste may travel a greater average distance within the receiving state than does endogenous waste. Absent that distinction, however, the third branch of the Complete Auto Transit test ${ }^{177}$ would render such a discriminatory tax unconstitutional. ${ }^{\mathbf{1 7 8}}$

\section{Reciprocal Symmetry}

A holdout state that requires little waste reduction of its residents, and relies instead on its more conservationist neighbors' disposal facilities, will attract jobs in waste-generating industries. Similarly, a state

tially a matter for legislative, and not judicial, resolution").

${ }^{174}$ The Commonwealth Edison Court gave great deference to Montana's determination of the per-ton tax rate both because courts lack the expertise to understand "the numerous and competing economic, geographic, demographic, social, and political considerations that must inform [such] a decision," $i d$. at 628 , and because taxation is a political question that "must be resolved through the political process." See id. The factual and technical issues involved in solid waste regulation are no less complex. More importantly, the valuation in dollar terms of environmental quality is an extremely sensitive political issue. For courts to assume the responsibility for that evaluation would damage their legitimacy. Cf. Mulhern, In Defense of Political Question Doctrine, 137 U. PA. L. REv. 97, 164-68 (1988) (discussing the importance of judicial deference in modern constitutional law).

${ }^{175}$ For a particularly blunt example, see Peterson, Motorists' Deaths Prompt an Uproar On Garbage Trucks at Jersey Landfill, N.Y. Times, May 26, 1987, at B2, col. 1 (describing an accident involving a truck carrying out-of-county garbage to controversial Edgeboro Landfill; the accident left six dead and provoked an uproar among residents of East Brunswick, New Jersey).

${ }^{176}$ Ohio has recently tried to push discriminatory taxation to its constitutional limit. It has imposed small statewide per-ton tipping fees that vary by the origin of the waste ( $\$ 0.50$ for waste from within the disposing solid waste management district, $\$ 1.00$ for waste from another Ohio district, and $\$ 1.50$ for waste from out of state; each figure will rise by $\$ 0.20$ over two years). See OHo REv. Code ANN. $\$ 3734(\mathrm{~A})$ (Anderson 1988). Moneys thus collected will be reserved for hazardous waste management and cleanup. See id. It has also authorized the county-level solid waste management districts to impose additional three-tiered fees in the same 1:2:3 ratio; money from the discriminatory last third of the fee on out-of-state waste is reserved exclusively for inspecting such waste. See id. $\$ \S 3734.57$ (B), (E)(6); see also Celebrezze, State Solid Waste Regulation and the Commerce Clause: Ohio's Initiative on a National Problem, 1 V.I.E.W. Proc. 49, 51-52 (1988); Kelly, supra note 6, at 18.

177 See supra notes $164-74$ and accompanying text.

178 See Note, supra note 162, at 55-56 (predicting that a discriminatory fee bill introduced in the New Jersey assembly would not survive constitutional scrutiny because "[n]o state, through taxation, may attempt to give a competitive advantage to local business to the detriment of out-of-state business"). 
that refuses to site disposal facilities and relies instead on its neighbors' facilities will avoid both environmental externalities and political headaches. Fear of these outcomes may lead states to bar disposal facilities from exporting capacity to states with less burdensome waste reduction requirements or less aggressive siting policies. ${ }^{179}$ The courts should generally uphold such symmetry requirements.

The symmetry requirements posited here must be distinguished from the reciprocity requirements that the Supreme Court has in two recent cases found violative of the commerce clause. In Great Atlantic E Pacific Tea Co. v. Cottrell, ${ }^{180}$ the Court struck down a Mississippi regulation against importing milk produced in states that did not reciprocally accept Mississippi milk. ${ }^{181}$ In Sporhase v. Nebraska ex rel. Douglas, ${ }^{\mathbf{1 8 2}}$ the Court extended its condemnation of reciprocity requirements to include export limitations. ${ }^{183}$ In both cases, the Court held that reciprocity requirements cannot be justified as a means to ward off protectionism, so long as the courts and the dormant commerce clause remain available to exorcise it completely. But while the courts can strike down protectionist laws, they lack the power and the institutional competence to order states to produce less waste and to site more disposal facilities. Thus a symmetry requirement may have a legitimate purpose-that of preventing states from free-riding on their neighbors' efforts. ${ }^{184}$

Nonetheless, symmetry requirements might be attacked an attempts by one state to foist onto its neighbors its own judgments as to optimal levels of waste reduction and disposal. ${ }^{185}$ This argument has

178 Cf. infra notes 188-192 and accompanying text (discussing an Oklahoma statute forbidding waste importation from states lacking disposal standards substantially similar to Oklahoma's).

180424 U.S. 366 (1976).

181 See id. at 381. Mississippi required imported milk to be inspected under standards "substantially equivalent" to Mississippi's. The law also required states exporting milk to Mississippi to accept Mississippi milk meeting the accepting state's own health and safety standards. See id. at 367-68 n.1, 367-77 n.9.

182458 U.S. 941 (1982).

${ }^{183}$ See id. at 957-58. Concerned about depletion of the Oglalla aquifer, Nebraska restricted withdrawal of groundwater from in-state wells. It barred withdrawal for export to any state which did not export an equal quantity of water to Nebraska. See id. at 944.

184 See Regan, supra note 22, at 1271 (suggesting that denying landfill space to all entities, local or not, that fail to comply with waste reduction measures is not purposeful discrimination and should be allowed).

${ }^{188}$ See, e.g., Great Atl. \& Pac. Tea Co., 424 U.S. at 381 (arguing that states are not permitted under the commerce clause to force their own judgments on other states "at the pain of an absolute ban" on interstate commerce); see also Regan, supra note 22 , at 1271 (stating that while symmetry requirements should be permitted, their extraterritoriality may "raise eyebrows"). 
two elements. One is that courts should allow states to internalize externalities only through excise taxes. ${ }^{186}$ The strengths and limitations of that argument have already been discussed. ${ }^{187}$

Also implicit, however, is an argument that any attempt to reshape the incentives surrounding other states' legislative decisions is illegitimate. The Tenth Gircuit appears to have been moved by this argument in striking down an Oklahoma law ${ }^{\mathbf{1 8 8}}$ excluding hazardous industrial wastes originating in states that had not enacted "substantially similar standards" for their disposal. ${ }^{189}$ This argument makes no sense in the modern legal universe that gives the states power to decide whether to adopt a free market or regulatory approach. ${ }^{190}$ Every regulation and every regulatory vacuum shapes the incentives affecting other political entities. Oklahoma's neighbors could as easily be accused of enacting laissez-faire standards for hazardous waste disposal that "reach[] out and seek[] to force the enactment"191 by Oklahoma of a statute with low standards similar to their own. ${ }^{\mathbf{1 9 2}}$ Given this relativity, to label a state as an aggressor solely because it is the first to move from laissezfaire to regulation is to turn the commerce clause back into a tool for exposing state governments to the efficiency-maximizing wind stirred by the mobility of capital. ${ }^{193}$

186 Rather than ration disposal capacity to residents of equally conservationist/ aggressive states, a state could sell it at a price high enough to compensate the state for all its costs. Its neighbors could then decide whether they wish to pay that price or to step up their own waste reduction and/or facility siting efforts. See supra text accompanying notes 158-63.

${ }_{187}$ As already noted, see supra text accompanying notes $164-74$, the free-rider problem might also be remediable through excise taxes. However, when there exists a genuine shortage of disposal capacity, an administrable excise tax might not adequately slow the flow of waste into the state. In such circumstances, some form of rationing may be required. A symmetry requirement is a justifiable way to prefer those nonresidents who are working to alleviate the shortage over those who are not.

188 See Okla. Stat. tit. 63, § 2764 (Supp. 1978).

189 See Hardage v. Atkins, 619 F.2d 871, 873 (10th Cir. 1980) (Hardage II) (holding unconstitutional a requirement that waste-exporting state's disposal laws be "substantially similar" to receiving state's laws, even divorced from a reciprocity requirement that the exporting state accept Oklahoma waste); Hardage v. Atkins, 582 F.2d 1264, 1266 (10th Cir. 1978) (Hardage I) (holding that those two requirements taken together violate dormant commerce clause).

190 See B. ACKERMAN, supra note 67 , at $1-2$ \& n.1.

191 Hardage II, 619 F.2d at 873.

182 From all that appears in the several opinions resulting from this case, Oklahoma may have feared the loss of industry to states with looser disposal standards, the loss of disposal capacity to states with tighter disposal standards, or both. The discussion assumes the first of these possibilities.

${ }_{193}$ See R. Jackson, The Struggle For Judicial Supremacy: A Study of a Grisis in American Power Politics 21-22 (1941) (stating that special economic interests may masquerade as states' rights arguments); cf. Hammer v. Dagenhart, 247 U.S. 251, 255 (1918) (argument for appellant) (unsuccessfully urging the Court to uphold congressional prohibition on interstate commerce in the products of child labor 


\section{County Self-Sufficiency}

Right alongside the trend towards statewide solid waste planning successfully promoted by Congress, ${ }^{194}$ a trend has arisen towards states encouraging or requiring that their political subdivisions-typically counties-dispose of their own waste. ${ }^{195}$ States of course have the police power to regulate the intrastate flow of endogenously generated waste. ${ }^{198} \mathrm{~A}$ dormant commerce clause issue arises, however, when taxes or prohibitions on the disposal of out-of-district waste are applied not only to waste coming from areas of the state outside the receiving subdivision, but to waste from other states.

The mere fact that such statutes do not mention state boundaries in so many words will not save them from commerce clause attack. Either because they come so close as to be indistinguishable from statutes that purposefully discriminate on their face, ${ }^{197}$ or because they have a clearly discriminatory effect, ${ }^{198}$ they are subject to the strict scrutiny of "virtual[] per se . . . invalidity."199

States that can demonstrate "some reason, apart from their origin,

on grounds that nationwide competition made regulation by individual states impossible, and conceding that for the same reason a state law "forbidding entrance into the State of goods made by children of an age lower than that at which the State itself permits young persons to work would perhaps be valid in the absence of congressional legislation"), overruled United States v. Darby, 312 U.S. 100, 116 (1941) (noting that the "power of Congress under the Commerce Clause is plenary to exclude any article from interstate commerce subject only to the specific prohibitions of the Constitution").

194 See Resource Conservation and Recovery Act of 1976, Pub. L. No. 94-580, 90 Stat. 2795 (codified as amended in scattered sections of 42 U.S.C. $\$ \S 6901-86$ (1982 \& Supp. IV 1986 \& West Supp. 1988)).

195 See, e.g., Monroe-Livingston Sanitary Landfill, Inc. v. Town of Caledonia, 51 N.Y.2d 679, 684-85, 417 N.E.2d 78, 80-81, 435 N.Y.S.2d 966, 968-69 (1980) (upholding against commerce clause attack a municipal ban on disposing of out-of-town waste in the town's privately-owned landfill); N.J. STAT. ANN. \$ 13:1E-138(c) (West 1988) (imposing a tax on the importation of solid waste into a county solid waste management district of $\$ 1$ per ton in 1985 , rising to $\$ 4$ per ton in 1988 , and increasing by $\$ 2$ each year thereafter).

${ }_{196}$ See, e.g., City of Elizabeth v. State Dep't of Envtl. Protection, 198 N.J. Super. 41, 50-52, 486 A.2d 356, 361-62 (1984) (upholding state regulation of intrastate waste flow); Monroe, 51 N.Y.2d at $684-85,417$ N.E.2d at 80,435 N.Y.S.2d at 968 (finding an ordinance excluding out-of-town refuse to be a legitimate exercise of the town's police power); see also Central Iowa Refuse Sys. Inc. v. Des Moines Metro. Solid Waste Agency, 715 F.2d 419 (1983), cert. denied, 471 U.S. 1003 (1985) (agency requirement that all waste generated in metropolitan area flow to its landfill is state action exempt from antitrust scrutiny).

187 See Philadelphia v. New Jersey, 437 U.S. 617, 618, 628-29 (1978); Dean Milk Co. v. City of Madison, 340 U.S. 349, 354 (1951); Regan, supra note 22, at 1229-30.

${ }^{188}$ See Pike v. Bruce Church, Inc., 397 U.S. 137, 145-46 (1970).

108 See Philadelphia v. New Jersey, 437 U.S. at 624. 
to treat . . . differently"200 out-of-state waste can, however, avoid such scrutiny" and come in under the easier "balancing" test of Pike $v$. Bruce Church, Inc. ${ }^{202}$ New Jersey secured an injunction closing Kinsley Landfill to Philadelphia during a shortage of disposal capacity (thus winning the war whose first battle Philadelphia had won in the Supreme Court) by establishing that Philadelphia waste was different. New Jersey convinced state trial and appellate judges that Philadelphia was better able than the towns of the host county to find alternative disposal sites. ${ }^{203}$ Externalities caused by the mere transportation of waste might also differentiate out-of-state and local waste. ${ }^{204}$ Whether to recognize the costs engendered by parochial sentiments as providing a distinction between local and outside waste is more problematic. ${ }^{205}$

Absent such factors, however, county self-sufficiency statutes should be evaluated for dormant commerce clause purposes as though their only effect were on other states. From the perspective of other states, with which a properly comity-oriented court ${ }^{206}$ should empathize, it is little consolation that a resource-rich neighbor has compartmentalized its wealth. ${ }^{207}$ The present inquiry thus collapses into that pursued above.

Ohio has recently adopted legislation that is likely to prevent any significant increase in importation, but should nonetheless survive dormant commerce clause scrutiny. Under the "service area" concept advanced by Ohio Attorney General Anthony Celebrezze, Jr., each disposal facility will normally serve only a designated area, drawn to fit into a statewide coordination plan. ${ }^{208}$ While the service area limitations are required to be consistent with ten-year projections of waste importation, ${ }^{209}$ the law may effectively prevent all but established exogenous

200 See id. at 627.

${ }^{201}$ See id.; $c f$. United Bldg. \& Constr. Trades v. Mayor of Camden, 465 U.S. 208,222 (1984) (finding a similar distinction in privileges \& immunities clause analysis).

202397 U.S. 137, 142 (1970); see supra note 82.

203 See Borough of Glassboro v. Gloucester County Bd., 100 N.J. 134, 145-47, 495 A.2d 49, 55-56 (1985).

${ }^{204}$ See supra notes $175-77$ and accompanying text.

200 See supra notes $142-44$ and accompanying text.

${ }^{206}$ See supra notes 40-41 and accompanying text.

207 See United Bldg. \& Constr. Trades v. Mayor of Camden, 465 U.S. 208, 217 $\mathrm{n} .9$ (1983); see also id. at $232 \mathrm{n} .14$ (Blackmun, J., dissenting) (discussing this issue in the privileges and immunities clause context).

${ }^{208}$ See Ohro Rev. Gode ANN. § 3734.53(c)(1) (Anderson 1988) (empowering waste management districts to exclude waste from outside the district-presumably including from other states-subject to preemption by the director of environmental protection); Celebrezze, supra note 176, at 51-52.

${ }^{209}$ See OHIo Rev. Code ANN. $\S \S 3734.53$ (A)(6), (C)(1) (Anderson 1988). 
sources from using Ohio's capacity. ${ }^{210}$ But this law should (narrowly) survive constitutional attack. ${ }^{211}$ A statewide coordination plan will generate real statewide public goods by extending and creating disposal capacity. Ohio should be allowed to keep what it creates.

\section{Federal Regulation}

In addition to its preemption power, Congress has "broad power to consent to state laws that would, in the absence of such consent, impose an impermissible burden on interstate commerce."212 To date, Congress has simply given the states a few small incentives to cooperate, with little effect. The Resource Conservation and Recovery Act of 1976 ("RCRA") ${ }^{213}$ encouraged the formation of waste disposal regions transcending state boundaries. ${ }^{214}$ Over the past decade, Congress appropriated $\$ 165$ million $^{215}$ for states with acceptable solid waste disposal plans. ${ }^{216}$ In its implementing regulations, the Environmental Protection Agency recommends, but does not require, that " $\mathrm{t}] \mathrm{he}$ State plan ... provide for substate cooperation and policies for free and unrestricted movement of solid and hazardous waste across State and local boundaries."217

Federal involvement will soon increase markedly. The Environmental Protection Agency is in the process of promulgating comprehensive performance standards for siting, operating, and closing landfills that receive household waste, as well as disclosure requirements for

${ }^{210}$ Out-of-state generators who someday want to increase their shipments to Ohio may well find that service area planners have left no room for them. Moreover, the law also freezes the daily tonnage each facility can accept until solid waste districts are established. See H.B. 592, § 6 (C), 117th Gen. Assembly, 1988 Ohio Legis. Bull. 54041 (Anderson), reprinted following OHo Rev. CODE ANN. $\$ 3734.52$ (Anderson 1988).

${ }_{211}$ Cf. Kelly, supra note 6, at 18 (noting that Celebrezze proposal was advanced as a modification of an outright blockade in order to save it from commerce clause attack).

${ }^{212}$ Hellerstein, supra note 118 , at 55 ; see supra note 30 and accompanying text. An admittedly weak argument could be made that by not exercising its special power over the District of Columbia to repeal the ordinance banning exogenous waste from district-owned landfills, see supra text accompanying note 15, Congress has affirmatively endorsed parallel state laws.

${ }_{213}$ Pub. L. No. 94-580, 90 Stat. 2795 (1976) (codified in scattered sections of 42 U.S.C. $\$ \S 6901-6987$ (1982 \& Supp. IV 1986 \& West Supp. 1988)).

${ }^{214}$ See 42 U.S.C. § 6946 (1982). That RCRA did not preempt state regulation of solid waste, including import restrictions, was a secondary holding of Philadelphia $v$. New Jersey. See Philadelphia v. New Jersey, 437 U.S. 617, 620 n.4 (1978).

${ }_{215}$ See 42 U.S.C. $\S 6948$ (1982 \& Supp. IV 1986).

${ }^{216}$ The criteria for acceptable plans are set out at 42 U.S.C. $\S 6943$ (1982 \& Supp. IV 1986).

${ }^{217} 40$ C.F.R. § 256.42(h) (1988). 
landfills that accept only commercial solid waste. ${ }^{218}$ These regulations could become effective as early as 1990 . Active federal involvement in regulating disposal safety-and thereby making siting easier-is not necessary to justify federal regulation under the positive commerce clause. ${ }^{219}$ It may, however, diminish states' claims of the right to control disposal capacity within their territory. As the regulations currently stand, however, the states would retain primary responsibility for enforcing disposal standards, and would be allowed to impose standards more stringent than EPA's. ${ }^{220}$

Future regulations or acts of Congress could, for example, encourage recycling, ${ }^{221}$ impose minimum tipping fees, hasten disposal facility construction, ${ }^{222}$ require the formation of interstate compacts, ${ }^{223}$ establish multi-state disposal regions, or establish a liability rule under which states would be required to accept out-of-state generators' waste at a price determined by a third party. ${ }^{24}$

218 See EPA Solid Waste Disposal Facility Criteria, 53 Fed. Reg. 33,314 (1988) (to be codified, if adopted, at 40 C.F.R. $\$ \S 257,258$ ) (proposed Aug. 30, 1988) [hereinafter EPA Criteria]. Significantly, landfill operators would be required to ensure that they will have adequate funds available to pay for correcting known releases, closing the site, and caring for it after closure. See id. at 33,347-51; 33,3409-10 (to be codified at 40 C.F.R. § 258.32).

218 Waste disposal clearly has a substantial effect on interstate commerce. Note, however, that National League of Cities stated in dictum that "sanitation" is a "traditional governmental function." National League of Cities v. Usery, 426 U.S. 833, 85152 (1976).

${ }^{220}$ See EPA Criteria, supra note 218, at 33,381-83 ("EPA expects the states to assume the primary responsibility for implementing and enforcing the revised criteria, and a major EPA enforcement program is not envisioned. . . . [unless] states fail to assume their responsibility."); id. at 33,405 (to be codified at 40 C.F.R. $\S 258.1$ ) (noting that the purpose of regulation is "to establish minimum national criteria . . . for municipal solid waste landfills") (emphasis added).

${ }^{221}$ See Recommendations for EPA's RCRA Program, Inside EPA's Envt'l Pol'y Alert, Dec. 28, 1988, at 6, 6-9 (summarizing the pro-recycling platform presented by a coalition of thirty groups to the presidential transition team).

${ }^{222}$ Cf. Office of Solid Waste and EMERgency Response, U.S. Environmental Protection Agency, Assurance of Hazardous Waste Capacity: Guidance to State Officials 4 (1988) (fleshing out the requirements of $\S 104(c)(9)$ of the Comprehensive Environmental Response, Compensation, and Liability Act, under which federal Superfund money will soon be spent only in states able to assure EPA that they will maintain adequate capacity to dispose of their own hazardous wastes).

${ }^{223}$ See Florini, supra note 127, at 334-36 (suggesting the use of interstate compacts to deal with hazardous wastes); Kelly, supra note 6, at 18 (As part of his proposal, Ohio Attorney General Celebrezze "advocates that Congress amend RCRA to require that garbage be moved only between states that had entered a regional compact."). Note that this approach has been followed for low-level radioactive waste disposal. See supra note 10.

${ }^{224}$ See Solid Waste Disposal, supra note 130, at 48-52 (recommending that while federal involvement should continue to be more limited than the states', EPA should promulgate landfill performance standards, support research, provide increased 


\section{Conclusion}

Within the last few generations, we have come to "an awareness that the very structure of our society depends upon a continuing flow of self-conscious decisions made by politically accountable state officials."225 As humanity's power to either destroy or sustain environmental resources grows, we must assume a similar activist responsibility for nature. Shaping dormant commerce jurisprudence to enhance states' ability to benefit from responsible management of their natural resources would meet a small part of that ongoing challenge.

technical assistance, help states expedite siting, and promote source reduction and recycling).

225 B. ACKerman, supra note 67 , at 1. 


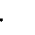

